\title{
Cell-free nucleic acid patterns in disease prediction and monitoring-hype or hope?
}

\author{
Adriana Torres Crigna ${ }^{1}$ - Marek Samec ${ }^{2}$ - Lenka Koklesova ${ }^{2}$ - Alena Liskova ${ }^{2}$ - Frank A. Giordano ${ }^{1}$ - Peter Kubatka ${ }^{3}$. \\ Olga Golubnitschaja ${ }^{4}$
}

Received: 15 September 2020 / Accepted: 7 October 2020 / Published online: 29 October 2020

(C) The Author(s) 2020

\begin{abstract}
Interest in the use of cell-free nucleic acids (CFNAs) as clinical non-invasive biomarker panels for prediction and prevention of multiple diseases has greatly increased over the last decade. Indeed, circulating CFNAs are attributable to many physiological and pathological processes such as imbalanced stress conditions, physical activities, extensive apoptosis of different origin, systemic hypoxic-ischemic events and tumour progression, amongst others. This article highlights the involvement of circulating CFNAs in local and systemic processes dealing with the question, whether specific patterns of CFNAs in blood, their detection, quantity and quality (such as their methylation status) might be instrumental to predict a disease development/progression and could be further utilised for accompanying diagnostics, targeted prevention, creation of individualised therapy algorithms, therapy monitoring and prognosis. Presented considerations conform with principles of 3P medicine and serve for improving individual outcomes and cost efficacy of medical services provided to the population.
\end{abstract}

Keywords Predictive preventive personalised medicine (PPPM/3PM) · Cell-free nucleic acids (CFNAs) $\cdot$ miRNA $\cdot$ Biomarker panel $\cdot$ Methylation status $\cdot$ Physical activity $\cdot$ Apoptosis $\cdot$ Systemic hypoxic-ischemic lesion $\cdot$ Tumour development progression $\cdot$

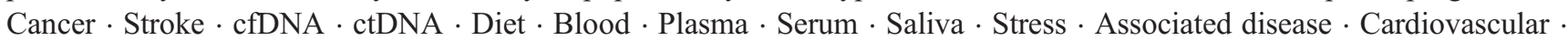
Neurologic · Virus · COVID-19 · Liquid biopsy · Therapy monitoring · Qualitative and quantitative analysis · Precancerous lesions $\cdot$ Mutations $\cdot$ Breast cancer $\cdot$ Colorectal cancer $\cdot$ Lung cancer $\cdot$ Prostate cancer $\cdot$ Diabetes $\cdot$ Metabolic disorder

\section{Liquid biopsy is instrumental for predictive diagnostics and targeted treatments}

$\overline{\text { Adriana Torres Crigna and Marek Samec contributed equally to this }}$ work.

\section{Peter Kubatka}

peter.kubatka@uniba.sk

$\triangle$ Olga Golubnitschaja

olga.golubnitschaja@ukbonn.de

1 Department of Radiation Oncology, University Hospital Bonn, Rheinische Friedrich-Wilhelms-Universität Bonn, Bonn, Germany

2 Department of Obstetrics and Gynecology, Jessenius Faculty of Medicine, Comenius University in Bratislava, 03601 Martin, Slovakia

3 Department of Medical Biology, Jessenius Faculty of Medicine, Comenius University in Bratislava, 03601 Martin, Slovakia

4 Predictive, Preventive, Personalised (3P) Medicine, Department of Radiation Oncology, University Hospital Bonn, Rheinische Friedrich-Wilhelms-Universität Bonn, Bonn, Germany
Liquid biopsy (LB) and individualised profiling of biomarker patterns presented in body fluids represent a revolutionary approach in the workframe of 3P medicine [1]. Current paper is dedicated to the liquid biopsy utilising specifically blood samples as the best explored source of information amongst other sorts of body fluids [2].

In the last years, cell-free nucleic acids (CFNAs) "signature" attracted a lot of attention for diagnostic and treatment purposes. Altered profiles of CFNAs have been detected under physiological conditions, e.g. by making sport, suboptimal conditions such as overtraining syndrome in physical exercises [3], acute and chronic pathological conditions including sepsis, stroke, trauma, myocardial infarction, autoimmune diseases and cancers [4]. To this end, certainly the area of oncological research is particularly advanced implementing ctDNA and miRNA detection and quantification for diagnostic and treatment purposes [5]. 
However, independently of the application area, the main goal remains the same, namely to look for pathology-specific patterns $[6-8]$ as well as for patterns clearly indicating associated risks, for example, in vasospastic individuals who may be particularly predisposed to an increased stress sensitivity [9-11], neuro/degenerative pathologies $[12,13]$ and/or aggressive metastasing cancers $[14,15]$.

\section{Diagnostic and prognostic potential of cell-free nucleic acids' signature in stress conditions and stress-related pathologies}

Dysregulation at the level of CFNAs acts as a promising diagnostic biomarker panel for measuring imbalanced stress and for predicting stress-associated pathologies. According to the World Health Organisation (WHO), stress presents the epidemic of the third millennium [16]. Accumulated evidence suggests a tight association between chronic stress and psychiatric disorders [17-21]. Especially severe, prolonged and/ or chronic stress of any origin such as exercise-induced oxidative stress [22] (see "Physical activity and exercise-induced oxidative stress" section), hormonal stress [23], emotional stress and psychological burden [24-27] as well as metabolic stress, e.g. in diabetes mellitus [28, 29] (see also below "Association between diabetes mellitus and carcinogenesis: diagnostic and therapeutic potential of cell-free nucleic acids" section) and hyperhomocysteinaemia [30,31] amongst others, is associated with highly increased ROS production and insufficient repair capacity - both linked to oxidative damage of mitochondria and consequent mitochondrial dysfunction leading to the development of cardiovascular impairments [32-34], neuro/degenerative pathologies [34-37], impaired healing [34] and malignant cell transformation [34, 38-42]. Noteworthy, the pathomechanisms carry a systemic character [43] that is crucial for tracing corresponding alterations in a minimally invasive manner utilising blood samples and other body fluids [1].

An application of liquid biopsy is a promising approach to identify biomarker patterns specific for stress and stressassociated diseases. Prominent examples are summarised below.

Acquired data revealed lower expression of serum miR-183 and miR-212 in major depressive disorder (MDD) patients after antidepressant therapy [44]. Further, miR-16, miR-135a and miR-1202 were significantly reduced in serum of patients diagnosed with depression compared with healthy individuals [45]. Plasma miR-134 (associated with the regulation of synaptic plasticity and neurogenesis) was downregulated in a cohort of patients with MDD compared with healthy controls. Measurements of miR-134 patterns are also useful to distinguish between MDD, bipolar disorder and schizophrenia [46]. Further, an increased expression of miR-124-3p has been detected in serum of antidepressant-free MDD patients compared with healthy controls [47]. Another study revealed significantly higher levels of plasma miR-451a and lower levels of miR-320 in a group of depressed patients [48]. Another study detected significantly higher levels of serum miR-221-3p, miR-34a-5p and let-7d-3p in patients with MDD compared with controls [49]. Moreover, depressive symptoms were associated with the downregulation of plasma miR-144-5p considered as a useful biomarker for pathological processes associated with depression [50].

Posttraumatic stress disorders (PTSDs) as a consequence of acute traumatic stress demonstrate specific patterns of miR142-5p, miR-19b, miR-1928, miR-223, miR-332, miR-324, miR-421-3p, miR-463 and miR-674. Anxiety and delayed fear are reflected in specific patterns of the panel comprising miR-142-5p, miR-1928, miR-223 and miR-19b [51] as detected, for example, in veterans suffering from PTSDs. To this end, miR-203a-3p derived from extracellular vesicles was upregulated, whilst miR-339-5p was downregulated in a cohort of PTSDs patients compared with controls [52]. Differentially expressed circulating miRNAs associated with PTSDs were detected in another study focused on stress-related disorders in the population of military veterans [53].

In a preclinical study, miR-24-2-5p, miR-27a-3p, miR-30e-5, miR-3590-3p, miR-532-5p and miR-362-3p patterns were decreased in rats with manifested vulnerability to chronic stress, whereas another panel comprising miR-28-3p, miR-139-5p, miR-326-3p and miR-99b-5p was downregulated in rats more resistant to stress - both compared with controls [54].

In the context of stress, cfDNA is an excellent biomarker candidate for clinical application considering circulating cellfree mitochondrial DNA (ccf-mtDNA). Correlation between serum ccf-mtDNA and psychological stress was demonstrated in the study focused on the cohort of healthy midlife adults. A brief psychological challenge in tested volunteers led to increased serum ccf-mtDNA, in contrast to circulating cellfree nuclear DNA [55]. Increased plasma concentrations of ccf-mtDNA have been demonstrated also for patients diagnosed with MDD and concluded as a biomarker associated with psychiatric disorders and useful for monitoring the pathology development and therapy response [56]. Table 1 summarises CFNAs associated with stress.

\section{Physical activity and exercise-induced oxidative stress}

Regular physical activity defined as movements of body mediated by skeletal muscles resulted in the energy expenditure usually measured in kilocalories [57] has been demonstrated as being crucial for physical and mental health benefits [58], prevention of various diseases including metabolic syndrome, obesity, insulin resistance, atherosclerosis, diabetes, neurodegenerative diseases and cancers [23-27]. Regular individually 
Table 1 CFNAs in psychological stress and stress-associated pathologies; explanatory note: $\uparrow$ increased levels, $\downarrow$ decreased levels

\begin{tabular}{|c|c|c|c|c|}
\hline Biomarker & $\begin{array}{l}\text { Liquid } \\
\text { biopsy } \\
\text { samples }\end{array}$ & Experimental design & Study results & Reference \\
\hline miRNA & Serum & Patients $(n=33)$ with MDD diagnosed and treated with antidepressants & $\downarrow$ miR-183; -212 & [44] \\
\hline miRNA & Serum & Patients $(n=39)$ with depression versus disease-free controls $(n=36)$ & $\downarrow$ miR-16; -135a; and -1202 & {$[45]$} \\
\hline miRNA & Plasma & $\begin{array}{l}\text { Patients with MDD ( } n=100) \text {, bipolar disorder }(n=50) \text {, schizophrenia } \\
\quad(n=50) \text { versus disease-free controls }(n=100)\end{array}$ & $\downarrow$ miR-134 & [46] \\
\hline miRNA & Serum & Patients $(n=18)$ with MDD versus disease-free controls $(n=17)$ & $\uparrow \operatorname{miR}-124-3 p$ & [47] \\
\hline miRNA & Plasma & Patients $(n=50)$ with depression versus disease-free controls $(n=41)$ & $\begin{array}{l}\uparrow \operatorname{miR}-451 \mathrm{a} \\
\downarrow \mathrm{miR}-320\end{array}$ & [48] \\
\hline miRNA & Serum & Patients $(n=32)$ with MDD versus disease-free controls $(n=21)$ & $\uparrow \mathrm{miR}-221-3 \mathrm{p} ;-34 \mathrm{a}-5 \mathrm{p} ;$ and let-7d-3p & [49] \\
\hline miRNA & Plasma & $\begin{array}{l}\text { Patients }(n=169) \text { with depressive disorders versus disease-free controls } \\
\quad(n=52)\end{array}$ & $\downarrow \mathrm{miR}-144-5 \mathrm{p}$ & {$[50]$} \\
\hline miRNA & Serum & Sprague Dawley rat model of PTSDs & $\begin{array}{l}\text { Dysregulation of miR-142-5p; -19b; } \\
\text {-1928; -223-3p; -332; -324; -421-3p; } \\
\text {-463; and -674 }\end{array}$ & {$[51]$} \\
\hline miRNA & Plasma & Military veterans with PTSDs $(n=10)$ and without PTSDs $(n=10)$ & $\begin{array}{l}\uparrow \operatorname{miR}-203 \mathrm{a}-3 \mathrm{p} \\
\downarrow \mathrm{miR}-339-5 \mathrm{p}\end{array}$ & {$[52]$} \\
\hline miRNA & $\begin{array}{l}\text { Peripheral } \\
\text { blood }\end{array}$ & Combat veterans $(n=24)$ with and without PTSDs & $\begin{array}{l}\uparrow \operatorname{miR}-19 \mathrm{a}-3 \mathrm{p} ;-101-3 \mathrm{p} ; 20 \mathrm{~b}-5 \mathrm{p} ;-20 \mathrm{a}-5 \mathrm{p} \\
\downarrow \text { miR-486-3p; }-128-3 \mathrm{p} ;-15 \mathrm{~b}-3 \mathrm{p} ; \\
\quad-125 \mathrm{~b}-5 \mathrm{p} ;\end{array}$ & {$[53]$} \\
\hline miRNA & Blood & Rat model of chronic social defeat & $\begin{array}{l}\downarrow \text { miR-24-2-5p; }-27 \mathrm{a}-3 \mathrm{p} ;-30 \mathrm{e}-5 \\
\quad-3590-3 \mathrm{p} ;-532-5 \mathrm{p} \text { and }-362-3 \mathrm{p}\end{array}$ & {$[54]$} \\
\hline ccf-mtDNA & Serum & Participants $(n=50)$ exposed to brief psychological challenge & $\uparrow \mathrm{ccf}-\mathrm{mtDNA}$ & {$[55]$} \\
\hline ccf-mtDNA & Plasma & Individuals ( $n=50$ ) with MDD versus disease-free controls $(n=55)$ & $\uparrow$ ccf-mtDNA & [56] \\
\hline
\end{tabular}

adapted exercise has an ability to inhibit ROS production, ameliorates the antioxidant capacity and improves mitochondria efficiency reducing oxidative stress and cellular damage [59]. Temporary increased levels of inflammation and cfDNA were observed in various acute exercises such as marathon, ultramarathon, resistance exercise, continuous, interval, and incremental treadmill running, and incremental rowing exercise [60-63]. However, during the period of physiologic recovery, the cfDNA levels usually come back to the baseline level [64]. In contrast, overtraining causes exercise-induced oxidative stress [22]. Consequently, the question is-how to distinguish between beneficial physical activity on one hand and damaging exercise-induced oxidative stress on the other hand, when providing recommendations at individual level? Circulating CFNAs might be helpful answering this question, since their patterns strongly depend on the intensity and duration of exercise being complementary to specific metabolic markers such as lactate and creatine kinase recognising muscle damage $[3,65]$. To this end, the overtraining and induced inflammation are well reflected in C-reactive protein (CRP) levels as the marker of inflammation and highly increased concentration of plasma cfDNA in proportion to training load [66]. In addition, there is no any significant difference in circulating cfDNA between obese and normal-weight subjects [67]. Noteworthy, although remaining unchanged in its absolute quantity, the proportional input by the foetal cfDNA is reduced in mother's blood by increased concentration of cfDNA linked to the exercise during and immediately after the physical activity. This proportion is normalised by $30 \mathrm{~min}$ after the exercise is finished [68].

The initiative called Education Outside the Classroom (EOtC) promoting physical activity against obesity in youth, has demonstrated increased level of cfDNA for bothsedentary behaviour and moderate-to-vigorous physical activity groups. Based on the results, the authors recommend light physical activity with the best potential to be supportive for health in examined children [69]. Further, diabetes predisposition can be diagnosed, e.g. in persons with sedentary lifestyle by applying miR-192 and miR-193b panel detected in the prediabetic stage but not in diabetic patients. Moreover, in glucose-intolerant mice and prediabetic individuals, regular exercises as a therapeutic strategy have normalised the miRNA patterns to the baseline level [70]. Furthermore, in healthy subjects, 74 circulating miRNAs associated with various heart diseases were evaluated at baseline, immediately after exercise and after $24 \mathrm{~h}$. Only miR$103 \mathrm{a}-3 \mathrm{p}$ was reduced in both types of exercises: $10 \mathrm{~km}$ and marathon races. Furthermore, increased serum levels of miR132-3p and miR-150-5p were detected forthwith after the 10$\mathrm{km}$ race. On the contrary, decreased serum levels of miR-103a$3 p$, miR-590-5p and miR-139-5p were observed in the same type of exercise. Moreover, decreased levels of miR-103a-3p and miR-375-5p were observed immediately after marathon race 
and remained low also after $24 \mathrm{~h}$. Further, several cardiac markers were upregulated and lasted for 24, 48 and/or $72 \mathrm{~h}$ after both exercises. Taken together, circulating miRNAs can be useful for patients with dysfunction symptoms after an acute attack of endurance physical activity [71]. Additionally, increased levels of circulating miRNAs including miR-126, miR-130b, miR-221 and miR-222 at baseline levels were detected in obese versus normal-weight subjects. These patterns but at higher levels were observed after acute aerobic exercise in obese subjects, even after controlling for $\mathrm{VO}_{2 \max }$ and insulin resistance (HOMA-IR) [72].

In summary, specific CFNAs patterns have been demonstrated in relationship to physical activity that allows to clearly differentiate between beneficial physical activity and exercise-induced oxidative stress and to provide accompanied diagnostics and individualised recommendations for healthy individuals and athletes, individuals in suboptimal health as well as for a variety of patients. Corresponding information is summarised in Table 2.

\section{Ischemic lesions and stroke}

Stroke is one of the leading and preventable causes of sudden death and the most common cause of long-term disability worldwide [73, 74]. Ischemic stroke (IS) accounts for approximately $80-85 \%$ of stroke cases against haemorrhagic one [75, 76]. In short, IS is associated with a cascade of events including cerebral ischemia, obstructions in cerebral blood flow, generation of reactive oxygen species, inflammatory processes, neuronal damage and apoptosis leading to neurological dysfunction [77]. IS is a heterogeneous, multifactorial disease associated with an interaction between genetic and modifiable risk factors [74]. Besides evident genetic predisposition, dietary patterns and lifestylerelated stressors strongly contribute to the development of IS [78]. Current diagnostic approaches applied for IS are not rarely associated with some obstacles such as prolonged time of the imaging performance, poor sensitivity and / or data interpretation, particularly in case of asymptomatic clinical picture [78]. To this end, so-called young stroke - the rapidly increasing patient cohort below 50 years of age with unclear aetiology - is particularly challenging for healthcare globally [13] demanding innovative solutions in the framework of 3P medicine. Phenotyping and blood-based biomarkers are currently under extensive consideration for the risk assessment and predictive diagnosis of IS $[13,79]$. To this end, the blood-brain barrier may prevent releasing brain-specific molecules into the bloodstream [80]. However, due to ischemia-related progressive cell death and consequent blood-brain barrier breakdown, the cfDNA release into the blood might accompany IS [77]. Moreover, due to chronic systemic effects, e.g. in vasospastic individuals predisposed to IS [13], a significant increase in the cfDNA blood concentration may happen days and weeks before the acute IS event.
Indeed, the cfDNA concentration correlates well with the severity at admission and with individual outcomes in IS patients [81] supporting meaningful measurements of plasma nuclear and mitochondrial cfDNA patterns [82] including specificity of the DNA fragmentation (300-400 bp range) profiling for diagnostic and prognostic purposes [77, 81-83].

miRNA panels provide complementary information in overall IS diagnostics: circulating exosomal miR-223 is significantly increased in acute IS against healthy controls, and its level correlates with stroke severity and individual outcomes [84]. In contrast, serum miR-221-3p and miR$382-5 p$ patterns are downregulated in IS patients against healthy controls [85]. Moreover, the combination of miR$21-5 p$ and miR-30a-5p was demonstrated as being of great utility to distinguish between hyper-acute, subacute and recovery phase of IS [80]. The miRNA panel comprising PC-3p-57,664, PC-5p-12,969, miR-122-5p and miR-211$5 \mathrm{p}$ demonstrates a correlation between upregulation in IS patients and post-mortem IS-brain specimens [86].

Table 3 summarises information on CFNAs in IS.

\section{Precancerous lesions and early cancer detection}

Liquid biopsy application to early cancer detection demands highly sensitive detection methodology in order to track circulating tumour DNA (ctDNA) amounts or diverse sub/ cellular structures secreted by precancerous lesions and/or at initial stages of cancer. For instance, testing viral sequences related to tumours, such as human papillomavirus (HPV) or Herpesvirus family (Epstein-Barr virus (EBV), cytomegalovirus (CMV) [87]), along with ctDNA methylation analysis is instrumental for diagnosing HPV-derived precancerous lesions. HPV 16 and 18 strains have been described as related to high risk, potentially leading to cervical cancer [88]. A cervical precancerous state is characterised by changes in collar cells making them more susceptible to cervix cancer development within 10-year time span, if not treated in a timely manner [89]. A meta-analysis study showed that despite the existing heterogeneity amongst studies, HPV cDNA detection is a specific and relatively sensitive tool for cervical cancer diagnosis [89]. Another study revealed the presence of HPV in 98.4\% of tumours, being HPV16 and 18 dependent for $89.4 \%$ of cervical cancer patients detected [87]. Likewise, RNA-seq database indicated the presence of HPV in the majority of cervical cancers [90]. In addition, EBV, CMV and Herpesvirus 6 (HHV6) were detected in 21 and $18 \%$ of rectal and colon cancers, respectively. EBV was found to be associated with $23 \%$ of stomach cancers. Herpesviruses are often detected in stomach, colon and rectum cancers. Some types of liver cancers have been linked with hepatitis $\mathrm{B}$ and $\mathrm{C}$ virus (HBV and HCV). HPV was present in a small amount of 
Table 2 Differences in CFNAs levels after acute or chronic exercises; explanatory note: $\uparrow$ increased levels, $\downarrow$ decreased levels

\begin{tabular}{|c|c|c|c|c|c|}
\hline Biomarker & $\begin{array}{l}\text { Liquid biopsy } \\
\text { samples }\end{array}$ & Experimental design & Type of exercise & Study results & Reference \\
\hline cfDNA & Plasma & $\begin{array}{l}17 \text { Recreationally trained men } \\
\text { (healthy volunteers); age, } \\
21.56(2.6) \text { years; body } \\
\text { weight, } 77 \text { (7.1) kg; body } \\
\text { height, } 1.77(0.11) \text { m; body } \\
\text { fat, } 12.2(2.1) \%\end{array}$ & $\begin{array}{l}\text { 12-week resistance training } \\
\text { regimen: } 8 \text { resistance } \\
\text { multi-joint exercises selected } \\
\text { to stress the entire muscula- } \\
\text { ture: bench press, squat, leg } \\
\text { press, snatch, hang clean, dead } \\
\text { lifts, barbell arm curls } \\
\text { and rowing }\end{array}$ & $\begin{array}{l}\uparrow \text { Cell-free plasma DNA } \\
\text { during } \mathrm{t} 1, \mathrm{t} 2 \text { and } \mathrm{t} 3 ; \uparrow \\
\mathrm{CRP}, \uparrow \text { creatine kinase; } \uparrow \\
\text { uric acid }\end{array}$ & {$[66]$} \\
\hline cfDNA & Plasma & $\begin{array}{l}n=14 \text { ( } 7 \text { obese and } 7 \\
\text { normal-weight) healthy male } \\
\text { subjects in the age of } 18-45\end{array}$ & $\begin{array}{l}\text { Treadmill - acute high-intensity } \\
\text { interval exercise ( } 30 \text { min of } \\
\text { total exercise, including a } \\
\text { 5-min warm-up period of } \\
\text { walking/jogging) }\end{array}$ & $\begin{array}{l}\text { Both obese and } \\
\text { normal-weight male: } \uparrow \\
\text { cfDNA, } \uparrow \text { IL-8 }\end{array}$ & {$[67]$} \\
\hline cfDNA & Plasma & $\begin{array}{l}\text { Nine pregnant women carrying } \\
\text { male foetuses at gestational } \\
\text { age } 12(+0) \text { weeks to } 14(+6) \\
\text { weeks }\end{array}$ & Cycling & $\begin{array}{l}\downarrow \text { Foetal cfDNA fraction, } \uparrow \\
\text { cfDNA of pregnant } \\
\text { women }\end{array}$ & {$[68]$} \\
\hline cfDNA & Saliva & $\begin{array}{l}\text { EOtC programme: fifth-grade } \\
\text { students ( } n=37 \text { with outdoor } \\
\text { lessons), control group ( } n=11 \\
\text { with indoor lessons) } \\
\text { (fall/spring/summer) }\end{array}$ & $\begin{array}{l}\text { Light physical activity and } \\
\text { moderate-to-vigorous physi- } \\
\text { cal activity }\end{array}$ & $\begin{array}{l}\text { Students with outdoor } \\
\text { lessons: } \downarrow \text { cortisol, } \uparrow \\
\text { cfDNA }\end{array}$ & [69] \\
\hline $\begin{array}{l}\text { Circulating miR-192 } \\
\text { and miR-193b }\end{array}$ & Serum & $\begin{array}{l}n=92 \text { male individuals with } \\
\text { different degrees of glucose } \\
\text { tolerance; } 6 \text {-week-old } \\
\text { C57BL } / 6 \mathrm{~J} \text { male mice }\end{array}$ & $\begin{array}{l}\text { Regular exercise (exercise } \\
\text { programme: twice per week } \\
\text { for } 16 \text { weeks) }\end{array}$ & $\begin{array}{l}\text { Prediabetic humans and } \\
\text { glucose-intolerant mice: } \uparrow \\
\text { miR-192, } \uparrow \\
\text { miR-193b;prediabetic } \\
\text { humans and } \\
\text { glucose-intolerant mice } \\
\text { with regular exercise: } \downarrow \\
\text { miR-192, } \downarrow \text { miR-193b }\end{array}$ & {$[70]$} \\
\hline $\begin{array}{l}74 \text { Circulating } \\
\text { miRNAs }\end{array}$ & Serum & $\begin{array}{l}\text { Healthy, highly trained } \\
\text { middle-aged amateur subjects } \\
(n=9)\end{array}$ & $\begin{array}{l}\text { 10-km race (half-marathon) and } \\
\text { marathon }\end{array}$ & $\begin{array}{l}\text { 10-km race: } \downarrow \text { miR-103a-3p, } \\
\uparrow \text { miR-132-3p, } \uparrow \\
\text { miR-150-5p, } \downarrow \\
\text { miR-590-5p, } \downarrow \\
\text { miR-139-5p } \\
\text { Marathon: } \downarrow \text { miR-103a-3p, } \downarrow \\
\text { miR-103a-3p, } \downarrow \\
\text { miR-375-5p }\end{array}$ & {$[71]$} \\
\hline $\begin{array}{l}\text { Circulating miR-126, } \\
\text { miR-130b, } \\
\text { miR-221, miR-222 }\end{array}$ & Plasma & $\begin{array}{c}N=24(12 \text { normal-weight } \\
\text { and } 12 \text { obese }) \text { subjects }\end{array}$ & $\begin{array}{l}\text { 30-min aerobic exercise } \\
\quad\left(75 \% \mathrm{VO}_{2 \max }\right)\end{array}$ & $\begin{array}{l}\text { After acute aerobic exercise } \\
\text { in obese subjects: } \uparrow \\
\text { miR-126, } \uparrow \text { miR-130b, } \uparrow \\
\text { miR-221, } \uparrow \text { miR-222 }\end{array}$ & {$[72]$} \\
\hline
\end{tabular}

$E O t C=$ education outside the classroom, $C R P=C$-reactive protein, $t 1, t 2, t 3=$ time poins, $I L-8=$ interleukin 8

bladder cancers along with a subset of head and neck cancers [87].

Premalignant neoplastic lesions, in particular, adenomas have often been detected to have distinct miRNA expression patterns. In a study assessing miRNA expression profiles of CRC and adenomas miR18a was upregulated in adenoma patients versus healthy controls [91]. A further study revealed ratios amongst three circulating miRNA to allow discriminating between benign prostate adenoma (hyperplasia) and prostate cancer in a more specific manner than standardised prostate-specific antigen (PSA) levels [92]. Another study described the use of several non-invasive biomarkers concomitantly (PSA together with androgen receptor CAG analysis and promoter methylation analysis) increasing predictive power of the prostate cancer and allowing its discrimination from benign prostate hyperplasia in $70-80 \%$ of cases [93].

Furthermore, quantitative and qualitative cfDNA characterisation has been described as capable to detect certain cancer types [94, 95], although being challenging yet for cancer screening application [96], since cfDNA origin, specificity and release kinetics have still to be clarified [97-100]. Plasma levels of short and long fragmented DNA and total cfDNA in oral cancer and precancerous lesions were evaluated and 
Table 3 CFNAs as a biomarker panel in ischemic stroke

\begin{tabular}{|c|c|c|c|c|}
\hline Biomarker & $\begin{array}{l}\text { Liquid } \\
\text { biopsy } \\
\text { samples }\end{array}$ & Experimental design & Study results & Reference \\
\hline cfDNA & Plasma & Ischemic stroke patients $(n=26)$ & $\begin{array}{l}\text { Correlation of cfDNA levels with severity of stroke } \\
\text { at admission and poor outcome within } 3 \text { months }\end{array}$ & {$[81]$} \\
\hline cfDNA & Plasma & Ischemic stroke patients $(n=54)$ & $\begin{array}{l}\text { Higher cfDNA associated with severity at the time } \\
\text { of admission and poor outcomes }\end{array}$ & {$[77]$} \\
\hline cfDNA fragments & Plasma & $\begin{array}{l}\text { Ischemic stroke patients } \\
\qquad \begin{array}{l}(n=48) \text { versus healthy controls } \\
(n=20)\end{array}\end{array}$ & $\begin{array}{l}\text { High abundance of plasma cfDNA fragments } \\
(300-400 \mathrm{bp}) \text { in ischemic stroke patients versus } \\
\text { healthy controls }\end{array}$ & {$[83]$} \\
\hline $\begin{array}{l}\text { Plasma nuclear and } \\
\text { mitochondrial DNA }\end{array}$ & Plasma & $\begin{array}{l}\text { Acute ischemic stroke patients } \\
\quad(n=50) \text { versus at risk control } \\
\text { subjects }(n=50)\end{array}$ & $\begin{array}{l}\text { Higher plasma nuclear and mitochondrial DNA in } \\
\text { acute ischemic stroke patients versus subjects at risk } \\
\text { Persistence of higher plasma nuclear DNA within } \\
1 \text { month after acute IS event } \\
\text { Positive correlation between plasma nuclear DNA } \\
\text { and clinical severity }\end{array}$ & {$[82]$} \\
\hline Exosomal miR-223 & Serum & $\begin{array}{l}\text { Acute ischemic stroke patients within } \\
72 \mathrm{~h}(n=50) \text { versus healthy } \\
\text { controls }(n=33)\end{array}$ & $\begin{array}{l}\text { Exosomal miR-223 correlated with NIHSS scores } \\
\text { Higher exosomal miR-223 associated with acute } \\
\text { ischemic stroke occurrence } \\
\text { Higher exosomal miR-223 in patients with poor } \\
\text { outcomes versus patients with good outcomes }\end{array}$ & {$[84]$} \\
\hline $\begin{array}{l}\text { Exosomal miRNA-21-5p in } \\
\text { combination with } \\
\text { miRNA-30a-5p }\end{array}$ & Plasma & Ischemic stroke patients $(n=143)$ & $\begin{array}{l}\text { Diagnosis of ischemic stroke } \\
\text { Distinguishing between hyper-acute, subacute and } \\
\text { recovery phases of ischemic stroke }\end{array}$ & {$[80]$} \\
\hline $\begin{array}{l}\text { miRNA-221-3p and } \\
\text { miRNA-382-5p }\end{array}$ & Serum & $\begin{array}{l}\text { Ischemic stroke patients }(n=78) \\
\text { versus healthy controls }(n=39)\end{array}$ & $\begin{array}{l}\text { Downregulated miRNA-221-3p and } \\
\text { miRNA-382-5p in ischemic stroke patients ver- } \\
\text { sus controls }\end{array}$ & {$[85]$} \\
\hline $\begin{array}{l}\text { miRNAs panel (PC-3p-57664, } \\
\text { PC-5p-12969, miR-122-5p, } \\
\text { miR-211-5p) }\end{array}$ & Serum & $\begin{array}{l}\text { Ischemic stroke patients }(n=34) \\
\text { versus healthy controls }(n=11)\end{array}$ & $\begin{array}{l}\text { Correlation between upregulation in ischemic } \\
\text { stroke patients and post-mortem ischemic } \\
\text { stroke-brain specimens }\end{array}$ & {$[86]$} \\
\hline
\end{tabular}

NIHSS National Institutes of Health Stroke Scale

quantified. Results demonstrated an increased cfDNA concentration and integrity of DNA in oral cancer compared with other cohorts, rendering it a tool for early oral cancer detection [101]. Further study evaluated somatic circulating mutations in patients with breast, lung, colorectal and ovarian cancers to assess cancer disease staging [102]. Data revealed overall significant increase of cfDNA in cancer patients' plasma compared with healthy subjects. Thereby, breast cancer cohort demonstrated the lowest mutant allele fraction of ctDNA. Noteworthy, advanced disease stages III and IV correlated with higher amount of ctDNA compared with early disease stages I and II across all cancer cohorts [102].

\section{Chronic inflammation in carcinogenesis reflected in CFNAs signature}

Chronic inflammation (together with infectious diseases related inflammation) is estimated to be responsible for approximately $25 \%$ of all cancer cases [103]. In the context of inflammatory milieu, epithelial and inflammatory cells secrete reactive oxygen and nitrogen species (ROS and RNS) causing DNA damage [104]. This DNA damage and mutagenic lesions, such as 8-oxo-7,8-dihydro-2'-deoxyguanosine (8oxodG) and 8-nitroguanine, occur in organs undergoing inflammation, eventually driving carcinogenesis [105]. Furthermore, parasites, viruses (HPV, EBV and hepatitis virus) and bacteria are considered to be pathogenic agents carcinogenic to humans [105]. Inflammation may also be promoted by physical, chemical and immunological factors [103, 106]. Chronic inflammation induces tissue injury, due to genetic and epigenetic aberrations, nucleic acid, lipid and protein damage via to ROS/RNS production. This tissue damage may activate tissue regeneration resulting from stimulation of progenitor/stem cells. Thus, accumulation of mutations in stem cells by ROS/RNS may result in mutant stem cells or cancer stem cells leading to carcinogenesis [105]. Consequently, detection of specific cfDNA, miRNA and methylation patterns are considered of great clinical utility for early cancer detection [107].

Indeed, cfDNA is known to accumulate under chronic inflammation, due to decreased clearance [108]. cfDNA, nuclear and mitochondrial DNA are actively secreted and mediate many processes such as immunomodulation, tumour growth progression and inflammation [108]. For instance, prostate carcinogenesis and disease progression are known 
to be promoted by chronic inflammation [109-111]. Risk factors related to prostatic inflammation are frequently related to immunological, genomic and environmental factors such as physical trauma, urinary microbial infection, chemical irritation, unhealthy diet and abnormal body weight $[112,113]$. Recruitment of leukocytes, namely macrophages, lymphocytes, granulocytes and monocytes to the prostate have been observed in the prostate cancer driven inflammation responses $[114,115]$. In advanced stages of prostate cancers, elevated peripheral blood neutrophil-to-lymphocytes ratios were observed, portraying worse overall survival (OS) and reduced sensitivity to chemotherapy and to anti-androgens [116].

\section{Cell-free nucleic acids in cancer management}

Although analysis of solid tumour tissues is a golden standard in oncology [117], tissue biopsies entail some risks for patients apart from being limited in identifying genetic heterogeneity or tracking neoplasm evolution alternations within a tumour [118]. Clinical and laboratory advances have broadened tumour-related diagnosis, prognosis and predictive measures. In fact, the use of cfDNA has marked a potential minimally-invasive alternative option for genomic diagnostics.

ctDNA was described to be the tumour-derived fraction of cell-free DNA secreted into the blood [119]. ctDNA patterns in blood are considered as being a potent analytical option alternative to solid tumour biopsies for cancer detection and monitoring, due to rapid, non-invasive and cost-effective biomarker identification [120]. Besides cfDNA/ctDNA, malignancy-related blood patterns include circulating miRNA, circulating tumour cells (CTCs) and exosomes [121, 122]. Notably, also saliva, cerebrospinal fluid (CSF), pleural fluid, urine and tears are prospective sources of tumour-originated material [123-127].

\section{ctDNA detection in a broad range of neoplasms}

ctDNA, released by cancer cells, have been identified in a broad range of neoplasm types both in early and late cancer stages, displaying levels from $<1$ to $>100,000$ mutated DNA fragments per $\mathrm{ml}$ of plasma. In cancer patients, ctDNA fractions differ greatly, fluctuating from less than $0.1 \%$ to more than $90 \%$ of overall cfDNA. There is an obvious great variability amongst ctDNA detected in patients with differing cancer type; however, variations in ctDNA fraction amongst patients with analogous tumour type may be attributed to biological disparities, as well as varying cell death rates within tumour cells [128-130]. Even though there are studies describing a correlation amongst the amount of cfDNA, cancer status and disease progression $[131,132]$, others reveal cfDNA quantification to be insufficient as an independent diagnostic tool, lacking information about tumour development $[133,134]$. cfDNA low circulation concentration together with its considerable proportion of fragmentation make it a challenging compound to analyse [135]. Furthermore, identification and evaluation of ctDNA within total cfDNA represent a great challenge in cancer detection [128-130]. Nevertheless, ctDNA bears the tumour specific molecular features capable of early cancer diagnosis and prediction as well as disease prognosis.

\section{ctDNA patterns advance diagnostic approach}

ctDNA has been detected in cancer patients' plasma prior to mainstream screening methods: mutation of KRAS2 and P53 in healthy subjects are described as related to an increased risk of developing bladder cancer within a period of 6 years [136]. Detection of plasma/serum DNA alterations at early tumour stages along with the current available markers renders ctDNA a useful diagnostic mean for early breast cancer [133]. Similarly, the quantification of DNA levels and microsatellite alterations in plasma DNA of lung cancer patients, suggested a correspondence with their clinical condition, serving additionally as non-invasive follow up assays [134]. In a metastatic breast cancer study a decrease in cfDNA integrity along with an increase in plasma cfDNA concentration has been described compared with healthy controls [137]. Another study analysed CRC patient samples in a quantitative and qualitative manner. Results revealed high plasma and serum cfDNA values at the time of surgery, which further increase in relapsed patients, confirming CRC and determining cancer status [94].

\section{ctDNA allows targeted cancer therapy}

The ability of tracking therapy response is one of the most significant traits of liquid biopsies, particularly in therapies with resistance mechanisms. KRAS mutations in colorectal tumour (CRC) progression are associated with acquired resistance and reduced response to anti-epidermal growth factor receptor (EGFR) therapies [138]. In a study comparing KRAS and BRAF mutations in both metastatic CRC plasma cfDNA and tumour tissue, specificity and sensitivity of $100 \%$ for BRAF V600E mutation and $96 \%$ on KRAS point mutations have been demonstrated. Thus, this study reveals high potential for developing better personalised medical services [139]. Furthermore, KRAS mutations were analysed in CRC samples, aiming to determine prevalence of KRAS amplification and evaluate its overall sensitivity to EGFR therapies. In presence of this genetic lesion, a lack of responsiveness to anti-EGFR inhibitors was found [138]. Similarly, another independent study revealed KRAS mutations to be common determinants of acquired resistance in $\mathrm{CRC}$ cancer patients [140]. 
Multiregional and shotgun sequencing of circulating tumour plasma DNA has revealed the potential to assess molecular heterogeneity of overall disease [141]. In a study quantifying ctDNA from CRC patients, ctDNA determination could track tumour dynamics in patients subjected to chemotherapy or surgery, revealing a potential customisable genetic approach [128]. Similarly, ctDNA was detected in $97 \%$ of patients with metastatic breast cancer with somatic genomic modifications, and identified tumour dynamics greater than CA 15-3 or CTC [129]. Another study testing prostate cancer plasma samples determined the genomic scenario and disease progression through the analysis of ctDNA in a non-invasive manner [142].

\section{ctDNA in therapy monitoring and prognosis}

Circulating tumour DNA patterns have been described as a non-invasive biomarker able to detect marginal disease residues after surgery or neoplastic therapies [143-146]. Detection of ctDNA at time of diagnosis in NSCLC patients together with residual ctDNA is associated with poor prognosis [147]. Furthermore, a study revealed the prognostic capacity of ctDNA in plasma from CRC patients to determine survival rates and increased patient recurrence [148]. Elevated levels of cfDNA and plasma mutant KRAS levels (pmKRAS) were described to be directly correlated, making plasma cfDNA to an alternative prognosis biomarker [149]. Similar data were published by Dawson et al. for the breast cancer patient cohort [129]. In an advanced non-small cell lung cancer (NSCLC) patient study, ctDNA appeared to be more sensitive to mutation detection than CTC [150]. An independent study also indicated ctDNA to be a potent prognostic biomarker [151]

Measuring plasma or serum ctDNA profiles to monitor cancer development is a promptly developing field with great clinical potential. Studies focused on ctDNA as a tool for cancer diagnostic, prediction and/or prognosis are summarised in Table 4. ctDNA analysis may reinforce its use as personalised treatments for cancer patients. Nevertheless, validating studies are essential to bring this tool into daily clinical practice.

\section{miRNA panels in cancer management-prominent examples}

Anomalous miRNA patterns have been correlated with pathogenicity of several human cancers [187]. Overexpression of miRNA in cancer prompts their action as tumour suppressors or oncogenes depending on the target [188]; some miRNA may act as both concomitantly. Tumour-related miRNA are more stable to processing than other molecules, making them optimal tumour biomarkers [127]. Studies utilising miRNA as non-invasive biomarkers for cancer detection are summarised in Table 5.

Colorectal cancer $\mathrm{Ng}$ et al. described the significant overexpression of miR-17-3p and miR-92 in plasma from CRC patients versus control subjects. miR-92 marker specifically differentiates CRC from gastric cancer markers, making it to more sensitive CRC marker [152]. Similarly, a meta-analysis observed an increase in miR-17 in plasma/serum/faecal levels of CRC patients, with $68 \%$ specificity [156]. miR-92a together with miR-21 was highly increased in serum samples, possessing prognostic value in CRC patients [156]. Further, results from the analysis of CRC patient plasma revealed significant upregulation of a miRNA panel (miR-15b, miR-18a, miR-19a, miR-19b, miR-29a and miR-335) depicting different miRNA expression patterns amongst CRC patients and healthy subjects [91]. Further experiments validated these results, with $91 \%$ sensitivity and $90 \%$ specificity for CRC and advanced adenoma (AA) detection and prognosis [153]. Plasma miR-18 [154] and serum miR-19a [155, 160] have also been described to be significantly increased in CRC patients in comparison with healthy controls. miR-29a has also shown an important role as a potential biomarker for CRC detection. Furthermore, miR-29a combined with miR-92a are capable to distinguish advanced CRC from healthy subjects with $83 \%$ sensitivity and $84.7 \%$ specificity [158].

miR-21 has been extensively reported in multiple cancers as promoting proliferation and tumour growth, being one of the most relevant diagnostic miRNA oncogenes in tumour onset [189]. A study testing 380 miRNA described 19 dysregulated miRNA in CRC patient plasma samples. miR-21 upregulation discriminated CRC patients from healthy subjects with a sensitivity and specificity of 90\% [159]. Furthermore, two independent studies revealed upregulation of miR-21 levels in CRC patients compared with controls even years prior to the clinical manifestation of the disease $[160,161]$.

Exosomal miRNAs, although still insufficiently investigated, are increasingly applied as biomarkers for cancer detection featuring high specificity. For instance, increased serum levels of exosomal miR-19a and miR-92a in CRC patients against controls have been detected [162]. Similarly, upregulation of serum exosomal miR-21 and miR-23 amongst others, was described in CRC patients [163].

Breast cancer In breast tumour studies, many differentially expressed miRNA have been detected in breast cancer patients compared with healthy women. miR-1, miR92a, miR-133a and miR-133b have been described as some of the most prevalent upregulated biomarkers in breast cancer samples [164]. Another study revealed miR-182 serum levels to be increased in patients with breast cancer versus controls. Furthermore, serum miR-182 levels were significantly lower in oestrogen receptor (ER)- and progesterone receptor (PR)- 
Table 4 ctDNA as a biomarker for neoplastic detection, predictive diagnostics and prognosis

\begin{tabular}{lll}
\hline Procedure & Application & Reference \\
\hline Diagnosis & Early detection & {$[94,133,134,136,137]$} \\
Prediction & Molecular heterogeneity & {$[141]$} \\
& Tumour dynamic assessment & {$[128,129,142]$} \\
& Determination of early treatment response & {$[138,139]$} \\
& Acquired resistance & {$[138,140]$} \\
Prognosis & Detection of marginal disease residues & {$[143-146]$} \\
& Survival and recurrence rate & {$[148]$} \\
& Tumour load determination & {$[149]$} \\
\hline
\end{tabular}

positive breast cancer patients than those in ER- and PRnegative patients, demonstrating their clinical utility for breast cancer diagnosis [165]. Additionally, 4 upregulated plasma miRNA (miR-148b, miR-376c, miR-409-3p and miR-801) managed to discriminate breast cancer patients from controls [166]. miR-34a, miR-93 and miR-373 serum levels were distinguishable between M0 breast cancer patients on one hand and healthy subjects on the other hand, whilst miR-17 and miR-155 differentiated M0 from M1 patients [167]. Further studies described miR-21 and miR-146a as increased in plasma levels, therefore, distinguishing breast cancer patients from healthy controls [168]. Similarly, another study revealed miR-21 increased serum levels, which together with miR-10b, miR-125b, miR-145, miR-155 miR-191 and miR-382 are indicative for breast cancer occurrence [169]. Moreover, two independent studies have described miR-21 increase to be of importance to discriminate breast cancer patients from healthy women [170, 171]. Increased miR-21 concentrations corresponded with visceral metastasis [171]. miR-92 decreased levels along with elevated miR-21 were positively associated with lymph node detection and tumour size [170]. A microarray panel study analysing 1100 miRNAs found 59 differentially expressed miRNA in whole blood from early stage breast cancer patients against healthy individuals, from which 13 were up-regulated and 46 were downregulated [172]. Looking for differences specific for breast cancer, 8 up-regulated and one downregulated plasma miRNA were discovered: miR-16, miR-21 and miR-451 were significantly increased and miR-145 significantly reduced in breast cancer patients [173].

Lung cancer To date, lung carcinogenesis molecular signature has been mainly monitored through mRNA systematic analysis along with detection of protein expression levels [190]. However, miRNA expression pattern analysis may portray novel diagnostic and prognostic tools for predictive and early lung cancer detection [191]. Indeed, a study assessing miRNA expression in early-stage NSCLC serum samples revealed significantly increased miR-1254 and miR-574-5p levels, allowing for discrimination of NSCLC patients from controls with a $77 \%$ and $82 \%$ specificity and sensitivity, respectively, and in the validation cohort with a $71 \%$ specificity and $73 \%$ sensitivity [174]. Furthermore, 10 serum miRNA (miR-20a, miR-24, miR-25, miR-145, miR-152, miR199a-5p, miR-221, miR-222, miR-223 and miR-320) were detected to be differentially expressed in NSCLC serum patient samples compared with controls. This specific miRNA profiling was able to detect NSLCL 33 months prior to the clinical manifestation of the disease [175]. 34-miRNA signature model was created to detect early-stage NSCLC within a population of highrisk asymptomatic subjects with an $80 \%$ accuracy [176]. In another study, miR-21 increased levels positively correlated with lymph node and tumour-node metastases in NSCLC patients; shorter 3-year overall survival compared with patients with low levels of miR-21 expression was demonstrated [177]. Similarly, miR-21 as well as miR-126, miR-210 and miR-486-5p were detected as a potential NSCLC diagnostic panel, portraying $86.2 \%$ of sensitivity and $96.6 \%$ specificity [181]. Contrarily, another study found that miR-21 along with miR-15b, miR-17, miR-28-3p, miR-106a, miR-126, miR-142-3p, miR-148a, miR-197, miR-221 and miR-486-5p were decreased in poor prognosis lung cancer cases [180]. NSCLC serum patient study described increased levels of miR-30d and miR-486 together with decreased levels of miR-1 and miR-499 as correlated positively with poor NSCLC prognosis [178]. Plasma miRNA analysis revealed miR-155, miR-182 and miR-197 levels to be considerably higher in lung cancer patients than in controls with a sensitivity of $81.33 \%$ and a specificity of $86.76 \%$. Higher pattern values were detected in patients with metastasis than in those without [179]. Furthermore, miR-21, miR-126, miR-155 and miR-223 (84\% specificity and 83\% sensitivity) have arisen as a potential biomarker signature for lung cancer detection [182]. Altogether, these studies suggest that corresponding miRNA panels (but individual miRNAs) have a predictive power for lung cancer detection. 
Table 5 Circulating miRNA panels for cancer detection, monitoring and prognosis

\begin{tabular}{|c|c|c|c|c|}
\hline $\begin{array}{l}\text { Cancer } \\
\text { type }\end{array}$ & Biomarker & $\begin{array}{l}\text { Liquid biopsy } \\
\text { samples }\end{array}$ & Experimental design & Reference \\
\hline $\mathrm{CRC}$ & $\begin{array}{l}\text { miR-17-3p and miR-92 elevated in CRC } \\
\text { patients }\end{array}$ & Plasma & $\begin{array}{l}\text { Three phase study: (phase I) plasma and biopsies from } n=5 \\
\text { patients with CRC, } n=5 \text { healthy subjects; (phase II) } n=25 \\
\text { CRC patients, } n=20 \text { healthy subjects; (phase III) } n=90 \\
\text { CRC patients; } n=50 \text { healthy subjects (control); } n=20 \text { in- } \\
\text { flammatory bowel disease (IBD) patients and } n=20 \text { gas- } \\
\text { tric cancer (GC) patients were included to determine bio- } \\
\text { marker specificity }\end{array}$ & {$[152]$} \\
\hline $\mathrm{CRC}$ & $\begin{array}{l}\text { miR-15b, miR-18a, miR-19a, miR-19b, } \\
\text { miR-29a and miR-335 upregulated in } \\
\text { CRC patients, with respect to healthy } \\
\text { subjects }\end{array}$ & Plasma & $\begin{array}{l}n=123 \text { newly diagnosed patients with sporadic colorectal } \\
\text { neoplasia }(n=63 \text { with CRC and } n=60 \text { with AA) versus } \\
n=73 \text { healthy subjects (control) }\end{array}$ & {$[91]$} \\
\hline $\mathrm{CRC}$ & $\begin{array}{l}\text { miR-15b, miR-18a, miR-19a, miR-19b, } \\
\text { miR-29a and miR-335 upregulated in } \\
\text { CRC patients, with respect to healthy } \\
\text { subjects }\end{array}$ & Plasma & $\begin{array}{l}n=96 \text { CRC patients, } n=101 \text { diagnosed with AA versus } \\
n=100 \text { healthy subjects (control) }\end{array}$ & {$[153]$} \\
\hline $\mathrm{CRC}$ & miR-18a and miR-200c & Plasma & $n=78 \mathrm{CRC}$ patients versus $n=86$ healthy subjects (control) & {$[154]$} \\
\hline $\mathrm{CRC}$ & miR-17, miR-19a, miR-20a and miR-223 & Serum & $\begin{array}{l}\text { Two sample- set: } 1-n=30 \mathrm{CRC} \text { patients and } 2-n=100 \mathrm{CRC} \\
\text { patients (control subjects } \mathrm{n} / \mathrm{d} \text { ) }\end{array}$ & {$[155]$} \\
\hline $\mathrm{CRC}$ & $\operatorname{miR}-17$ & Serum/plasma/faecal & $\begin{array}{l}\text { Meta-analysis comprising } 10 \text { studies with a total } \\
n=938 \text { CRC patients and } n=638 \text { healthy subjects } \\
\text { (control). }\end{array}$ & {$[156]$} \\
\hline $\mathrm{CRC}$ & miR-21 and miR-92a & Serum & $\begin{array}{l}n=200 \text { CRC patients, } n=50 \text { advanced adenoma (AA) } \\
\text { patients, } n=80 \text { healthy subjects (control) }\end{array}$ & {$[157]$} \\
\hline $\mathrm{CRC}$ & miR-29a and miR-92a & Plasma & $\begin{array}{c}n=157 \text { patients total }(n=120 \mathrm{CRC} \text { patients and } n=37 \mathrm{AA}) \\
n=59 \text { healthy subjects (control) }\end{array}$ & {$[158]$} \\
\hline $\mathrm{CRC}$ & $\begin{array}{l}\text { Upregulation of miR-21, miR-31 and } \\
\text { miR-135b }\end{array}$ & Plasma & $n=66$ CRC patients, $n=50$ healthy subjects (control) & {$[159]$} \\
\hline $\mathrm{CRC}$ & miR-19a-3p, miR-21-5p and miR-425-5p & Serum & $n=196$ CRC patients, $n=138$ healthy subjects (control) & {$[160]$} \\
\hline $\mathrm{CRC}$ & miR-18a, miR-21, miR-22 and miR-25 & Plasma & $n=67 \mathrm{CRC}$ patients $($ control subjects $\mathrm{n} / \mathrm{d})$ & {$[161]$} \\
\hline CRC & Exosomal miR-19a and miR-92a & Serum & $n=227$ CRC patients, $n=28$ healthy subjects (control) & {$[162]$} \\
\hline $\mathrm{CRC}$ & $\begin{array}{l}\text { Exosomal miR-21, miR-23a, miR-150, } \\
\text { miR-223, miR-1229, miR-1246 and } \\
\text { let-7a }\end{array}$ & Serum & $\begin{array}{l}n=88 \text { primary CRC patients, } n=11 \text { healthy subjects } \\
\quad(\text { control })\end{array}$ & {$[163]$} \\
\hline Breast & $\begin{array}{l}\text { miR-1, miR-92a, miR-133a and miR-133b } \\
\text { (upregulated) }\end{array}$ & Serum & $\begin{array}{l}n=132 \text { breast cancer patients and } n=101 \text { healthy subjects } \\
\quad \text { (control) }\end{array}$ & [164] \\
\hline Breast & $\operatorname{miR}-182$ & Serum & $\begin{array}{l}n=46 \text { breast cancer patients and } n=58 \text { healthy subjects } \\
\quad(\text { control })\end{array}$ & {$[165]$} \\
\hline Breast & $\begin{array}{l}\text { miR-148b, miR-376c, miR-409-3p and } \\
\text { miR-801 }\end{array}$ & Plasma & $\begin{array}{l}n=127 \text { sporadic breast cancer cases and } n=80 \text { healthy } \\
\text { subjects (control) }\end{array}$ & {$[166]$} \\
\hline Breast & miR-34a, miR-93 and miR-373 & Serum & $\begin{array}{l}n=120 \text { patients with primary breast cancer (M0), } n=32 \\
\text { patients with overt metastasis (M1) and } n=40 \text { healthy } \\
\text { subjects (control) }\end{array}$ & {$[167]$} \\
\hline Breast & miR-21 and miR-146a & Plasma & $\begin{array}{l}n=14 \text { breast cancer patients and } n=8 \text { healthy subjects } \\
\quad(\text { control) }\end{array}$ & {$[168]$} \\
\hline Breast & $\begin{array}{l}\text { miR-10b, miR-21, miR-125b, miR-145, } \\
\text { miR-155, miR-191 and miR-382 }\end{array}$ & Serum & $\begin{array}{l}n=61 \text { breast cancer patients and } n=10 \text { healthy subjects } \\
\quad(\text { control) }\end{array}$ & [169] \\
\hline Breast & $\begin{array}{l}\text { Increased miR-21 levels and decreased } \\
\text { miR-92a levels }\end{array}$ & Serum & $\begin{array}{l}n=100 \text { serum samples of patients with primary breast cancer } \\
\text { versus } n=20 \text { healthy subjects (control) }\end{array}$ & {$[170]$} \\
\hline Breast & Increased miR-21 & Serum & $\begin{array}{l}n=102 \text { breast cancer patients of different stages versus } n=20 \\
\text { healthy subjects (control) }\end{array}$ & {$[171]$} \\
\hline Breast & $\begin{array}{l}13 \text { up-regulated miRNA and } 46 \text { downreg- } \\
\text { ulated miRNA ( } 59 \text { differentially } \\
\text { expressed) }\end{array}$ & Whole blood & $\begin{array}{l}n=48 \text { early stage breast cancer patients versus } n=57 \text { healthy } \\
\text { subjects (control) }\end{array}$ & {$[172]$} \\
\hline Breast & $\begin{array}{l}\text { miR-16, miR-21 and miR-451 significantly } \\
\text { increased and miR-145 significantly re- } \\
\text { duced in breast cancer patients }\end{array}$ & Plasma & $\begin{array}{l}\text { Case-control cohort: } n=170 \text { breast cancer patients versus } \\
n=100 \text { healthy subjects (control); validation test: } n=95 \\
\text { other types of cancers (blindly validated), } n=70 \text { breast } \\
\text { cancer patients, } n=50 \text { healthy subjects (control) }\end{array}$ & {$[173]$} \\
\hline Lung & miR-1254 and miR-574-5p & Serum & $\begin{array}{l}\text { Discovery cohort: } n=11 \text { patients with early-stage NSCLC } \\
\text { versus } n=11 \text { healthy subjects (control). Validation cohort: } \\
n=22 \text { patients versus } n=30 \text { controls }\end{array}$ & {$[174]$} \\
\hline
\end{tabular}


Table 5 (continued)

\begin{tabular}{|c|c|c|c|c|}
\hline $\begin{array}{l}\text { Cancer } \\
\text { type }\end{array}$ & Biomarker & $\begin{array}{l}\text { Liquid biopsy } \\
\text { samples }\end{array}$ & Experimental design & Reference \\
\hline Lung & $\begin{array}{l}\text { miR-20a, miR-24, miR-25, miR-145, } \\
\text { miR-152, miR-199a-5p, miR-221, } \\
\text { miR-222, miR-223 and miR-320 }\end{array}$ & Serum & $\begin{array}{l}n=400 \text { NSCLC serum patients versus } n=220 \text { healthy } \\
\text { subjects (control) }\end{array}$ & {$[175]$} \\
\hline Lung & 34 serum miRNA & Serum & $\begin{array}{l}\text { Two sets: } 1 \text {. training set: } n=25 \text { adenocarcinoma (AC) pa- } \\
\text { tients versus } n=39 \text { healthy subjects (control), } 2 \text {. testing set: } \\
n=22 \mathrm{AC}, 12 \text { squamous cell carcinomas (SCCs), } n=30 \\
\text { healthy subjects (control) }\end{array}$ & {$[176]$} \\
\hline Lung & $\operatorname{miR}-21$ & Serum & $\begin{array}{l}n=88 \text { NSCLC patients versus } n=17 \text { healthy subjects } \\
\quad(\text { control) }\end{array}$ & {$[177]$} \\
\hline Lung & $\begin{array}{l}\text { Increased miR-30d and miR-486 levels and } \\
\text { decreased miR-1 and miR-499 levels }\end{array}$ & Serum & $\begin{array}{l}\text { Total } n=303 \text { patients: } n=30 \text { patients with longer survival, } \\
n=30 \text { patients with shorter survival, } n=243 \text { NSCLC } \\
\text { patients in training set } n=120 \text { and testing set } n=123\end{array}$ & {$[178]$} \\
\hline Lung & miR-155, miR-182 and miR-197 & Plasma & $\begin{array}{l}n=74 \text { lung cancer patients ( } 33 \text { stages I-II, } 41 \text { stages III-IV) } \\
\text { versus } n=68 \text { healthy subjects (control) }\end{array}$ & {$[179]$} \\
\hline Lung & $\begin{array}{l}\text { Decreased miR-21 along with mir-15b, } \\
\text { mir-17, mir-28-3p, mir-106a, mir-126, } \\
\text { mir-142-3p, mir-148a, mir-197, mir-221 } \\
\text { and mir-486-5p levels }\end{array}$ & Plasma & $\begin{array}{l}n=40 \text { plasma samples ( } n=19 \text { patients in the training set and } \\
n=34 \text { plasma samples from } 22 \text { patients from the validation } \\
\text { set) and control were represented by } 15 \text { pools of } 5-7 \\
\text { healthy subject plasma samples }\end{array}$ & {$[180]$} \\
\hline Lung & $\begin{array}{l}\text { miR-21, miR-126, miR-210 and } \\
\text { miR-486-5p }\end{array}$ & Plasma & $\begin{array}{l}n=58 \text { NSCLC patients ( } 30 \text { Stage I-II, } 28 \text { Stage III-IV) } \\
\text { versus } n=29 \text { healthy subjects (control) }\end{array}$ & {$[181]$} \\
\hline Lung & miR-21, miR-126, miR-155 and miR-223 & Serum & $n=6919$ patients versus $n=7064$ healthy subjects (control) & {$[182]$} \\
\hline Prostate & miR-18a & Peripheral blood & $\begin{array}{l}n=24 \text { prostate cancer }(\mathrm{PC}) \text { patients, } n=24 \text { benign prostatic } \\
\text { hyperplasia }(\mathrm{BPH}) \text { patients and } n=23 \text { healthy subjects } \\
\quad(\text { control) }\end{array}$ & {$[183]$} \\
\hline Prostate & miR-141 & Serum & $\mathrm{n} / \mathrm{d}$ & {$[184]$} \\
\hline Prostate & $\operatorname{miR}-182-5 p$ and $\mathrm{miR}-375-3 p$ & Plasma & $\begin{array}{l}n=252 \text { prostate cancer patients versus } n=52 \text { healthy subjects } \\
\quad(\text { control })\end{array}$ & {$[185]$} \\
\hline Prostate & $\operatorname{miR}-372$ & Serum & $\begin{array}{c}n=20 \text { serum samples from prostate cancer patients versus } \\
n=20 \text { healthy subjects (control) }\end{array}$ & {$[186]$} \\
\hline
\end{tabular}

Prostate cancer Prostate cancer (PC) diagnosis, monitoring and prognosis are widely based on the androgen-regulated genes and prostate-specific antigen (PSA) [192]. In recent years, miRNA have been described to impact cancer features by either promoting (oncogenic miRNA) or suppressing (suppressive miRNA) tumour development and disease progression [193]. PC often presents with a deregulation of miRNA that may operate as oncogenes or tumour suppressors [194]. Indeed, increased miR-141 levels were shown in PC serum samples [184]. Increased expression of miR-18a was strongly correlated with promotion of PC, acting as an oncogenic miRNA allowing discrimination between $\mathrm{PC}$ and benign prostatic hyperplasia (BPH) [183]. Moreover, miR 182-5p and miR-375-3p blood levels were detected as non-invasive screening signature and potential prognostic biomarker for PC development [185].

There is an accumulated evidence of numerous miRNA tested in prostate cancer tissue samples acting as tumour suppressors [195, 196]. ERG is able to bind to miR-200b/ a/429 assisting transcription in PC cells in tumour tissues [196]. Moreover, miR-135a-1 was described to act as a potential tumour suppressor in metastatic PC by aiming at EGFR [195].

Another study revealed serum circulating miR-372 involvement in the progression of human PC by aiming p65mediated NF- $\mathrm{B} / \mathrm{MMP}-9 / \mathrm{PSA}$ signalling pathway. Thus, targeting miR-372/p65 interplay or interceding in miR-372 expression may present a valuable tool for diagnosis and treatment of PC patients [186]. However, studies addressing miRNA panels PC specificity for example against prostate inflammation are needed.

\section{Association between diabetes mellitus and carcinogenesis: diagnostic and therapeutic potential of cell-free nucleic acids}

Diabetes mellitus gathers several metabolic diseases characterised by a chronic state of hyperglycemia. It can result in a deficiency in secretion of insulin, lack of insulin effect or both simultaneously. Different types of diabetes exist, namely 
type 1, type 2 and gestational diabetes, that differ in genetics and aetiology [197]. Type 1 diabetes (T1D) is an autoimmune disorder characterised by hyperglycemia and $\beta$ cell destruction [198], whereas type 2 diabetes (T2D) is considered a metabolic syndrome.

\section{Diabetes and carcinogenesis}

Published epidemiological evidences portray a correlation between diabetes and cancer risk [199]. There are several potential risk factors common to both diseases, such as age, gender, diet, physical activity and obesity, amongst others [200]. Diabetic patients present increased blood glucose levels, along with advanced glycation endproducts (AGE) that eventually leads to higher levels of DNA damage [201]. Studies have described AGE capability to cause DNA strand breaks in colon and liver cells, as well as in murine podocytes. Metabolic stress, mitochondrial impairments and insufficient DNA repair increase risk of all-site carcinogenesis and cancer progression in diabetic patients $[38,201]$.

For example, correspondence between diabetes and CRC has been described in numerous studies [202]. In fact, a study revealed a 5-year decreased overall CRC, colon and rectal cancer survival $(18,19$ and $16 \%$, respectively) in patients with diabetes [203]. Another study showed an increased risk in diabetic women of developing CRC than men [204]. In women a direct risk by diabetes for breast cancer development has been described. A meta-analysis showed an increased cancer risk in diabetic women versus non-diabetic individuals [205]. A potential link between diabetes and breast cancer is promoted by oestrogen levels [206, 207].

In a lung cancer study contrasting lung cancer patients with and without diabetic history, diabetes was not a detrimental factor for lung cancer survival [208]. Prostate cancer and diabetes studies have resulted in dissimilar outcomes. For one, a meta-analysis study revealed diabetic men to have decreased risk of developing prostate cancer [209]. Another study described an increase in $29 \%$ in prostate cancer-related mortality in diabetic patients compared with non-diabetic subjects [210]. Obviously, a detailed patient stratification by individualised patient profiling is essential to bring more consensus in the data interpretation that allows for a disease prediction and of high quality personalised services to the patient [9].

Anti-diabetic drugs are known to decrease diabetes pathophysiological factors (high blood glucose and AGE), however, drugs such as metformin may also reduce risk of cancer in diabetic patients. In fact, studies have postulated anti-oxidant properties of anti-diabetic drugs and renin-angiotensin system inhibitors to potentially reduce cancer risk [211, 212].

\section{Diagnostic and therapeutic potential of cell-free nucleic acids in diabetes}

Determining differentially expressed miRNA or differentially methylated $\beta$ cell derived DNA might better identify T1D cohorts, as miRNA are known to be imperative in T1D pathogenesis and regulating $\beta$ cell function [213]. The use of proinsulin/ C-peptide (PI/C) ratios may support identification of $\beta$ cell destruction in subjects prior to the development of T1D, serving as a non-invasive marker of $\beta$ cell malfunction [214].

miRNA-375 has been reported as being one of the most abundantly expressed miRNA in $\beta$ cells. In fact, mice lacking miR-375 appeared to have decreased $\beta$ cell mass and increased glucagon secretion, resulting in a hyperglycemic state [215]. A similar study portrayed an overexpression of miR-375 in primary mouse islets [216]. Consequently, miR-375 was tested as a potential biomarker for diabetes. In fact, increased miR-375 was detected in mice prior to hyperglycemia onset [217]. miRNA-375 plasma levels were elevated in patients at 7 days post islet transplantation [218]. Serum miRNA sequencing analysis has identified miR-52, miR-24, miR-25, miR-26a, miR-27a, miR-27b miR-29a, miR-30a-5p, miR-148a, miR-181a, miR-200a and miR-210 as differentially expressed in T1D patients [219]. Further studies have tested miRNA patterns in immune cells from T1D patients, revealing an increased expression of miR-326 in lymphocytes from T1D subjects [220]. Another study determined decreased expression of miR-146 in PBMC from T1D patients against non-diabetic controls [221].

Evaluation of increased unmethylated insulin DNA in circulation is a key to detect evolution of T1D resulting from $\beta$ cell death [222]. Two independent studies revealed higher unmethylated to methylated insulin DNA ratios versus nondiabetic controls [223] and higher circulating levels of both methylated and unmethylated insulin DNA in early onset T1D patients [224]. Similarly, plasma cell-free DNA levels from new onset T1D and allogeneic islet transplantation subjects were higher than in controls [225, 226].

Furthermore, T2D patient's serum was tested for specific miRNA profiles: T2D were compared with obese patients and healthy controls. Combined miR-138 and miR-503 patterns enabled to discriminate between diabetic and obese diabetic patients. Further, using miR-15b in combination with miR-138 and miR-376a may help to distinguish between T2D and obesity. This evidence makes serum miRNA profiling to a potential T2D predictive tool [227]. Furthermore, a study which investigated plasma miRNA profiles in T2D patients revealed diminishing plasma levels of 10 miRNA and a slight increase of miR-28-3p. In fact, analysis of miR-15a, miR28-3p, miR-126, miR-223 and miR-320 represent a suitable T2DM signature array [228]. 
Table 6 Pathology-

specific CFNA panels

\begin{tabular}{|c|c|c|}
\hline Marker & Disease & Reference \\
\hline miR-20a-5p & Stress & {$[53]$} \\
\hline $\operatorname{miR}-16$ & Stress & {$[45]$} \\
\hline miR-30e-5 & Stress & {$[54]$} \\
\hline miR-221-3p & Stress & [49] \\
\hline miR-34-5p & Stress & [49] \\
\hline miR-135a & Stress & {$[45]$} \\
\hline miR-142-5p & Stress & {$[51]$} \\
\hline miR-223-3p & Stress & {$[51]$} \\
\hline miR-451a & Stress & {$[48]$} \\
\hline miR-320 & Stress & [48] \\
\hline let-7d-3p & Stress & [49] \\
\hline miR-124-3p & Stress & [47] \\
\hline miR-125b-5p & Stress & {$[53]$} \\
\hline miR-128-3p & Stress & {$[53]$} \\
\hline miR-101-3p & Stress & {$[53]$} \\
\hline miR-19a-3p & Stress & {$[53]$} \\
\hline miR-19b & Stress & {$[51]$} \\
\hline miR-20b-5p & Stress & {$[53]$} \\
\hline miR-20a-5p & Stress & {$[53]$} \\
\hline miR-15b-3p & Stress & {$[53]$} \\
\hline miR-134 & Stress & [46] \\
\hline miR-144-5p & Stress & {$[50]$} \\
\hline miR-183 & Stress & [44] \\
\hline miR-203a-3p & Stress & {$[52]$} \\
\hline miR-212 & Stress & [44] \\
\hline $\operatorname{miR}-27 a-3 p$ & Stress & {$[54]$} \\
\hline miR-324 & Stress & {$[51]$} \\
\hline miR-332 & Stress & {$[51]$} \\
\hline miR-339-5p & Stress & {$[52]$} \\
\hline miR-3590-3p & Stress & {$[54]$} \\
\hline miR-362-3p & Stress & {$[54]$} \\
\hline miR-421-3p & Stress & [51] \\
\hline miR-463 & Stress & {$[51]$} \\
\hline miR-486-3p & Stress & {$[53]$} \\
\hline miR-532-5p & Stress & {$[54]$} \\
\hline miR-674 & Stress & {$[51]$} \\
\hline miR-1202 & Stress & {$[45]$} \\
\hline miR-1928 & Stress & {$[51]$} \\
\hline miR-24-2-5p & Stress & {$[54]$} \\
\hline miR-132-3p & Physical activity & {$[71]$} \\
\hline miR-150-5p & Physical activity & [71] \\
\hline miR-375-5p & Physical activity & {$[71]$} \\
\hline C-reactive protein (CRP) & Physical activity & {$[66]$} \\
\hline miR-103a-3p & Physical activity & {$[71]$} \\
\hline miR-130b & Physical activity & {$[72]$} \\
\hline miR-192 & Physical activity & {$[70]$} \\
\hline miR-193b & Physical activity & {$[70]$} \\
\hline miR-590-3p & Physical activity & [71] \\
\hline miR-382-5p & Ischemic stroke & {$[85]$} \\
\hline
\end{tabular}


Table 6 (continued)

\begin{tabular}{|c|c|c|}
\hline Marker & Disease & Reference \\
\hline miR-122-5p & Ischemic stroke & {$[86]$} \\
\hline miR-211-5p & Ischemic stroke & {$[86]$} \\
\hline PC-3p-57,664 & Ischemic stroke & {$[86]$} \\
\hline PC-5p-12,969 & Ischemic stroke & {$[86]$} \\
\hline miR-19a & CRC cancer & {$[91,153,155,162,203]$} \\
\hline $\operatorname{miR}-135 b$ & CRC cancer & {$[159]$} \\
\hline miR-150 & CRC cancer & {$[163]$} \\
\hline $\operatorname{miR}-200 \mathrm{c}$ & CRC cancer & {$[154]$} \\
\hline miR-335 & CRC cancer & {$[91,153]$} \\
\hline miR-34a & Breast cancer & {$[167]$} \\
\hline miR-382 & Breast cancer & [169] \\
\hline miR-146a & Breast cancer & {$[168]$} \\
\hline miR-451 & Breast cancer & {$[173]$} \\
\hline miR-30d & Lung cancer & {$[178]$} \\
\hline miR-142-3p & Lung cancer & {$[180]$} \\
\hline miR-197 & Lung cancer & {$[179,180]$} \\
\hline $\operatorname{miR}-486-5 p$ & Lung cancer & {$[178,180,181]$} \\
\hline miR-135a-1 & Prostate cancer & {$[236]$} \\
\hline miR-141 & Prostate cancer & {$[184]$} \\
\hline miR-182-5p & Prostate cancer & {$[185]$} \\
\hline miR-372 & Prostate cancer & {$[186]$} \\
\hline miR-375-3p & Prostate cancer & {$[185]$} \\
\hline Proinsulin/C-peptide (PI/C) & Diabetes & {$[214]$} \\
\hline $\operatorname{miR}-15 \mathrm{a}$ & Diabetes & {$[228]$} \\
\hline miR-26a & Diabetes & [219] \\
\hline $\operatorname{miR}-27 a$ & Diabetes & [219] \\
\hline miR-27b & Diabetes & [219] \\
\hline miR-52 & Diabetes & [219] \\
\hline miR-138 & Diabetes & [227] \\
\hline miR-146 & Diabetes & [221] \\
\hline miR-181a & Diabetes & [219] \\
\hline miR-200a & Diabetes & [219] \\
\hline miR-326 & Diabetes & [220] \\
\hline miR-375 & Diabetes & [215-217] \\
\hline miR-376a & Diabetes & [227] \\
\hline
\end{tabular}

\section{Pathology-specific versus common cell-free nucleic acid patterns}

Imbalanced stress- and ischemia-related disorders, diabetes and cancer share several risk factors such as toxic environment, suboptimal life-style and dietary habits, specific phenotypes, vasospasm, accelerated ageing and abnormal body weight (both underweight and obesity), amongst others [9, 10, 13, 113, 229-232].

To this end, diabetes mellitus has been demonstrated as a prominent example of cancer risk factor [200]. Unfortunately, in many cases, studies do assess potential biomarkers out of context of collateral pathologies and potentially related health conditions that has been strongly criticised in the literature [233]. Those deficits should be compensated via well designed further studies, on one hand to indicate common origin and molecular pathways involved in several and collateral pathologies [234]. On the other hand, pathology-specific patterns are of great value for predictive diagnostic purposes, targeted prevention and cost-effective personalisation of medical services [6, 235].

Table 6 provides examples for pathology-specific and Table 7 for common CFNA panels in health conditions and disorders which the current paper has referred to. 
Table 7 Common CFNA panels

\begin{tabular}{|c|c|c|}
\hline Marker & Disease & Reference \\
\hline miR-15b & CRC cancer-lung cancer-diabetes & {$[91,180,227]$} \\
\hline miR-16 & Stress-breast cancer & {$[44,45,173]$} \\
\hline $\operatorname{miR}-17$ & CRC cancer-lung cancer & {$[155,156,180]$} \\
\hline miR-18a & $\mathrm{CRC}$ cancer-prostate cancer & {$[91,153,154,183]$} \\
\hline $\operatorname{miR}-19 a-3 p$ & Stress-CRC cancer & {$[53,160]$} \\
\hline miR-19b & Stress-CRC cancer & {$[51,91,153]$} \\
\hline miR-20a & CRC cancer-lung cancer & {$[155,175]$} \\
\hline $\operatorname{miR}-21$ & CRC cancer-breast cancer-lung cancer & $\begin{array}{l}{[157,159,160,163,168-171,173,177,} \\
\quad 180-182]\end{array}$ \\
\hline $\operatorname{miR}-21-5 p$ & Ischemic stroke-CRC cancer & {$[80,160]$} \\
\hline $\operatorname{miR}-24$ & Lung cancer-diabetes & {$[175,219]$} \\
\hline $\operatorname{miR}-25$ & Lung cancer-diabetes & {$[175,219]$} \\
\hline $\operatorname{miR}-28-3 p$ & Stress-lung cancer-diabetes & {$[54,180,228]$} \\
\hline miR-29a & CRC cancer-diabetes & {$[91,153,158,219]$} \\
\hline $\operatorname{miR}-30 a-5 p$ & Ischemic stroke-diabetes & {$[80,219]$} \\
\hline miR-92a & CRC cancer-breast cancer & {$[158,162,164,170]$} \\
\hline miR-126 & Physical activity-lung cancer-diabetes & {$[72,180-182,228]$} \\
\hline miR-139-5p & Stress-physical activity & {$[54,71]$} \\
\hline miR-145 & Breast cancer-lung cancer & {$[169,173,175]$} \\
\hline miR-148a & Lung cancer-diabetes & {$[180,219]$} \\
\hline miR-155 & Breast cancer-lung cancer & {$[169,179,182]$} \\
\hline miR-182 & Stress-breast cancer-lung cancer & {$[44,165,179]$} \\
\hline miR-210 & Lung cancer-diabetes & {$[181,219]$} \\
\hline miR-221 & Physical activity-lung cancer & {$[72,175,180]$} \\
\hline $\operatorname{miR}-221-3 p$ & Stress-ischemic stroke & {$[49,85]$} \\
\hline miR-222 & Physical activity-lung cancer & {$[72,175]$} \\
\hline miR-223 & $\begin{array}{l}\text { Stress-ischemic stroke-CRC cancer-lung } \\
\text { cancer-diabetes }\end{array}$ & {$[51,84,155,163,175,182,228]$} \\
\hline miR-320 & Stress-lung cancer-diabetes & {$[48,175,228]$} \\
\hline
\end{tabular}

\section{Pathology-specific CFNA panels}

Predominant CFNAs signatures for stress are miR-3590-3p, miR-362-3p, miR-421-3p [51, 54]. Several experimental and clinical studies identified dysregulation in others stress associated miRNA panels: miR-183; -212; -16; 135a; -1202;-134; -124-3p; -451a; -320; -221-3p; -34a-5p; let-7d-3p; -144-5p; $142-5 \mathrm{p} ;-19 \mathrm{~b} ;-1928 ;-223-3 \mathrm{p} ;-332 ;-324 ;-463$; and -674; 203a-3p; -339-5p; -19a-3p; -101-3p; 20b-5p; -20a-5p; -4863p; -128-3p; -15b-3p; -125b-5p; -24-2-5p; -27a-3p; -30e-5; 532-5p [44-54]. Some studies analysed cfDNA [66-69] as well as circulating miRNA panels (miR-192; -193b; -126; 130b; -221; -222) [70-72] after acute and chronic exercise. Last but not least circulating miRNA (miR-223; -21-5p; -30a5p; -221-3p; -382-5p; -122-5p; -211-5p; PC-3p-57,664; PC$5 p-12,969)$ [80, 84-86], cfDNA and mtDNA could act as promising diagnostic and prognostic biomarkers of ischemic stroke [77, 81-83].

The miR-19a dysregulation has been described in numerous studies related to CRC cancer patients compared with controls
[91, 153, 155, 160, 162]. Moreover, miR-335 was also detected in CRC tumours by several different groups [91, 153]. Breast cancer specific biomarkers detected are miR-34a, miR-382, miR146a and miR-451 [167-169, 173]. Patterns of miR-197 [179, $180]$ and miR-486-5p [178, 180, 181] have been analysed as pathology-specific biomarkers in lung cancer patients. Moreover, prostate cancer specific biomarkers are miR-135a-1, miR-141, and miR-372, amongst others [184, 186, 195].

One of the most prominent diabetes mellitus biomarker is miR-375 [215-217] along with further biomarkers described as specific for diabetes detection such as the panel of miR138, miR-181a, miR-326 and miR-376a, amongst others [219, 220, 227]. Table 6 summarises pathology-specific CFNA panels.

\section{Common CFNA panels}

Comprehensive analysis demonstrated common CFNA panels amongst different diseases. For instance, miR-21 has been described to be present in CRC, breast and lung cancers. miR-21- 
5p and miR-223 are related to both ischemic stroke and CRC cancer. Furthermore, miR-223 has been described for lung cancer, ischemic stroke, diabetes and stress-related diseases. Lung cancer shares several miRNA markers with stress-related disorders (miR-28-3p, miR-182, miR-223 and miR-320) and physical activity (miR-126, miR-221 and miR-222). miR-16 and miR182 are present in both breast cancer and stress-related diseases. Moreover, miR-15b, miR-24, miR-25, miR-28-3p, miR-126, miR-148a and miR-320 were present in lung cancer and diabetic patients. Dysregulation of miR-21, miR-145 and miR-155 have been found in both breast and lung cancer patients. Whereas, miR-15b, miR-17and miR-20a are common markers in CRC and lung cancers.

Table 7 summarises common CFNA panels. Further studies addressing interrelations amongst human disorders and shared CFNAs signature are essential.

\section{What is known about CFNAs signature utility in COVID-19 management?}

Many research teams around the world are intensively working on prediction of the COVID-19 epidemics, protective measures to populations, therapeutic and vaccination issues. It has been clearly demonstrated that lack of specific diagnostic laboratory tools may lead to incorrect political decisions causing either unnecessary overprotection of the population that is risky for a long-term economic recession, or underprotection of the population leading to a post-containment pandemic rebound [237, 238].

Blood parameters are highly indicative for the patient stratification, disease cause and individual outcomes [239]. Patients demonstrating severe course of COVID-19-related disease suffer from cytokine storms and multiorgan failure [240]; however, the underlying mechanisms still remain uncertain. Available information demonstrates that profuse innate immune responses aggravate individual outcomes [241]. Viral infections have been described to prompt cellular necrosis, which amplifies anti-viral immune responses releasing damage associated molecular patterns (DAMPs) [242]. Severely affected cells and tissues intrinsically secrete CFNAs such as mitochondrial DNA (MT-DNA) [243]. It has been demonstrated that COVID-19 patients with increased levels of MT-DNA are at elevated death risk, necessity of ICU care and intubation. Consequently, cell-free MT-DNA is a potential biomarker for individualised survival status prediction [243].

\section{PPPM-related conclusions}

LB and individualised profiling of biomarker patterns presented in body fluids represent a revolutionary approach in the work-frame of $3 \mathrm{P}$ medicine. In the last years,
CFNAs signature attracted a lot of attention for diagnostic and treatment purposes. Altered profiles of CFNAs have been detected under both physiological and pathological conditions. Although oncological research is particularly advanced implementing CFNAs for diagnostic and treatment purposes, independently of the application area, the main goal remains the same, namely to look for pathology-specific biomarker patterns as well as for patterns clearly indicating associated risks, for example, in vasospastic individuals who are a prominent example of patients predisposed to an increased stress sensitivity, neuro/degenerative disorders and/or aggressive metastasing cancers as discussed above. This article highlights the involvement of CFNAs in local and systemic processes dealing with the question, whether specific patterns of CFNAs in blood, their detection, quantity and quality (such as methylation status) might be instrumental to predict a disease development/progression and could be further utilised for accompanying diagnostics, targeted prevention, creation of individualised therapy algorithms, therapy monitoring and prognosis. Presented considerations conform with principles of 3P medicine [244] and can be implemented for improving individual outcomes and cost-efficacy of medical services provided to the population.

Author contributions OG and PK have coordinated the project and created the concepts of the study. ATC, MS, LK, AL and OG have performed literature search and drafted the manuscript. ATC, MS, FAG, PK and OG have elaborated on the final version of the manuscript. All authors have read and approved the final version.

Funding Open Access funding enabled and organized by Projekt DEAL.

\section{Compliance with ethical standards}

Conflict of interest The authors declare that they have no conflict of interest.

List of abbreviations 8-oxodG, 8-Oxo-7 8-dihydro-2'-deoxyguanosine; AA, Advanced adenoma; AGE, Advanced glycation end-products; BPH, Benign prostatic hyperplasia; ccf-mtDNA, Circulating cell-free mitochondrial DNA; cfDNA, Cell-free DNA; CFNA, Cell-free nucleic acid(s); CMV, Cytomegalovirus; CRC, Colorectal tumours; CRP, C-reactive protein; CSF, Cerebrospinal fluid; CTC, Circulating tumour cells; ctDNA, Circulating tumour DNA; DAMPs, Damage-associated molecular patterns; EBV, Epstein-Barr virus; EGFR, Epidermal growth factor receptor; EOtC, Education Outside the Classroom; ER, Oestrogen receptor; HBV, Hepatitis B; HCV, Hepatitis C; HHV6, Herpesvirus 6; HPV, Human papillomavirus; IS, Ischemic stroke; LB, Liquid biopsy; MDD, Major depressive disorder; MT-DNA, Mitochondrial DNA; NSCLC, Non-small cell lung cancer; OS, Overall survival; PC PI/C, Prostate cancer proinsulin/C-peptide; pmKRAS, Plasma mutant KRAS; PPPM / 3 PM, Predictive preventive personalised medicine; PR, Progesterone receptor; PSA, Prostate-specific antigen; PTSD, Posttraumatic stress disorders; RNS, Reactive nitrogen species; ROS, Reactive oxygen species; T1D, Type 1 diabetes; T2D, Type 2 diabetes; WHO, World Health Organisation 
Open Access This article is licensed under a Creative Commons Attribution 4.0 International License, which permits use, sharing, adaptation, distribution and reproduction in any medium or format, as long as you give appropriate credit to the original author(s) and the source, provide a link to the Creative Commons licence, and indicate if changes were made. The images or other third party material in this article are included in the article's Creative Commons licence, unless indicated otherwise in a credit line to the material. If material is not included in the article's Creative Commons licence and your intended use is not permitted by statutory regulation or exceeds the permitted use, you will need to obtain permission directly from the copyright holder. To view a copy of this licence, visit http://creativecommons.org/licenses/by/4.0/.

\section{References}

1. Gerner C, Costigliola V, Golubnitschaja O. Multiomic patterns in body fluids: technological challenge with a great potential to implement the advances paradigm of 3P medicine. Mass Spectrom Rev. 2019;39(5-6):442-51. https://doi.org/10.1002/mas.21612.

2. Liskova A, Samec M, Koklesova L, Giordano FA, Kubatka P, Golubnitschaja O. Liquid biopsy is instrumental for 3PM dimensional solutions in cancer management. J Clin Med. 2020;9:2749. https://doi.org/10.3390/jcm9092749.

3. Vittori LN, Tarozzi A, Latessa PM. Circulating cell-free DNA in physical activities. Methods Mol Biol Clifton NJ. 1909;2019:18397. https://doi.org/10.1007/978-1-4939-8973-7 14.

4. Swarup V, Rajeswari MR. Circulating (cell-free) nucleic acids-a promising, non-invasive tool for early detection of several human diseases. FEBS Lett. 2007;581:795-9. https://doi.org/10.1016/j. febslet.2007.01.051.

5. Fernández-Lázaro D, García Hernández JL, García AC, Córdova Martínez A, Mielgo-Ayuso J, Cruz-Hernández JJ. Liquid biopsy as novel tool in precision medicine: origins, properties, identification and clinical perspective of cancer's biomarkers. Diagn Basel Switz. $2020 ; 10: 215$. https://doi.org/10.3390/ diagnostics 10040215 .

6. Lu M, Zhan X. The crucial role of multiomic approach in cancer research and clinically relevant outcomes. EPMA J. 2018;9:77102. https://doi.org/10.1007/s13167-018-0128-8.

7. Stastny I, Dankova Z, Kajo K, Kubatka P, Golubnitschaja O, Zubor P. Aberrantly methylated cfDNA in body fluids as a promising diagnostic tool for early detection of breast cancer. Clin Breast Cancer. 2020;16:S1526-8209. https://doi.org/10.1016/j. clbc.2020.05.009.

8. Zubor P, Kubatka P, Kajo K, Dankova Z, Polacek H, Bielik T, et al. Why the gold standard approach by mammography demands extension by multiomics? Application of liquid biopsy miRNA profiles to breast cancer disease management. Int J Mol Sci. 2019;20:2878. https://doi.org/10.3390/ijms20122878.

9. Golubnitschaja O, Flammer J. Individualised patient profile: clinical utility of Flammer syndrome phenotype and general lessons for predictive, preventive and personalised medicine. EPMA J. 2018;9:15-20. https://doi.org/10.1007/s13167-018-0127-9.

10. Kunin A, Polivka J Jr, Moiseeva N, Golubnitschaja O. "Dry mouth" and "Flammer" syndromes-neglected risks in adolescents and new concepts by predictive, preventive and personalised approach. EPMA J. 2018;9:307-17. https://doi.org/10.1007/ s13167-018-0145-7.

11. Polivka J Jr, Polivka J, Pesta M, Rohan V, Celedova L, Cevela R, et al. "Young stroke" risks potentially linked to the flammer syndrome phenotype: facts and hypotheses. In Flammer Syndrome: From Phenotype to Associated Pathologies, Prediction, Prevention and Personalisation. In: Golubnitschaja $\mathrm{O}$, editor. Advances in Predictive, Preventive and Personalised Medicine.
Cham: Springer International Publishing; 2019. p. 165-81. ISBN 978-3-030-13550-8.

12. Konieczka K, Ritch R, Traverso CE, Kim DM, Kook MS, Gallino A, et al. Flammer syndrome. EPMA J. 2014;5:11. https://doi.org/ 10.1186/1878-5085-5-11.

13. Polivka J Jr, Polivka J, Pesta M, Rohan V, Celedova L, Mahajani $\mathrm{S}$, et al. Risks associated with the stroke predisposition at young age: facts and hypotheses in light of individualized predictive and preventive approach. EPMA J. 2019;10:81-99. https://doi.org/10. 1007/s13167-019-00162-5.

14. Bubnov R, Polivka J Jr, Zubor P, Konieczka K, Golubnitschaja O. "Pre-metastatic niches" in breast cancer: are they created by or prior to the tumour onset? "Flammer syndrome" relevance to address the question. EPMA J. 2017;8:141-57. https://doi.org/10. 1007/s13167-017-0092-8.

15. Polivka J Jr, Kralickova M, Polivka J, Kaiser C, Kuhn W, Golubnitschaja O. Mystery of the brain metastatic disease in breast cancer patients: improved patient stratification, disease prediction and targeted prevention on the horizon? EPMA J. 2017;8: 119-27. https://doi.org/10.1007/s13167-017-0087-5.

16. Anusha AS, Joy J, Preejith SP, Joseph J, Sivaprakasam M. Differential effects of physical and psychological stressors on electrodermal activity. Conf Proc Annu Int Conf IEEE Eng Med Biol Soc IEEE Eng Med Biol Soc Annu Conf. 2017;2017:4549 52. https://doi.org/10.1109/EMBC.2017.8037868.

17. Salleh MR. Life event, stress and illness. Malays J Med Sci MJMS. 2008;15:9-18.

18. Hassanzadeh A, Heidari Z, Feizi A, Hassanzadeh Keshteli A, Roohafza H, Afshar H, et al. Association of stressful life events with psychological problems: a large-scale community-based study using grouped outcomes latent factor regression with latent predictors. Comput Math Methods Med. 2017;2017. https://doi. org/10.1155/2017/3457103.

19. Yazdi M, Roohafza H, Feizi A, Rabiei K, Sarafzadegan N. The influence of dietary patterns and stressful life events on psychological problems in a large sample of Iranian industrial employees: structural equations modeling approach. J Affect Disord. 2018;236:140-8. https://doi.org/10.1016/j.jad.2018.04.120.

20. Low NC, Dugas E, O'Loughlin E, Rodriguez D, Contreras G, Chaiton M, et al. Common stressful life events and difficulties are associated with mental health symptoms and substance use in young adolescents. BMC Psychiatry. 2012;12:116. https://doi. org/10.1186/1471-244X-12-116.

21. Davis MT, Holmes SE, Pietrzak RH, Esterlis I. Neurobiology of chronic stress-related psychiatric disorders: evidence from molecular imaging studies. Chronic Stress. 2017;1. https://doi.org/10. 1177/2470547017710916.

22. Powers SK, Radak Z, Ji LL. Exercise-induced oxidative stress: past, present and future. J Physiol. 2016;594:5081-92. https:// doi.org/10.1113/JP270646.

23. Chiarello DI, Abad C, Rojas D, Toledo F, Vázquez CM, Mate A, et al. Oxidative stress: Normal pregnancy versus preeclampsia. Biochim Biophys Acta (BBA) - Mol Basis Dis. 1866;2020: 165354. https://doi.org/10.1016/j.bbadis.2018.12.005.

24. Petzold MB, Plag J, Ströhle A. Dealing with psychological distress by healthcare professionals during the COVID-19 pandemia. Nervenarzt. 2020;91:417-21. https://doi.org/10.1007/s00115020-00905-0.

25. Shen X, Zou X, Zhong X, Yan J, Li L. Psychological stress of ICU nurses in the time of COVID-19. Crit Care. 2020;24:200. https:// doi.org/10.1186/s13054-020-02926-2.

26. Sabel BA, Wang J, Fähse S, Cárdenas-Morales L, Antal A. Personality and stress influence vision restoration and recovery in glaucoma and optic neuropathy following alternating current stimulation: implications for personalized neuromodulation and 
rehabilitation. EPMA J. 2020;11:177-96. https://doi.org/10.1007/ s13167-020-00204-3.

27. Grigorescu S, Cazan A-M, Rogozea L, Grigorescu DO. Original targeted therapy for the management of the burnout syndrome in nurses: an innovative approach and a new opportunity in the context of predictive, preventive and personalized medicine. EPMA J. 2020;11:161-76. https://doi.org/10.1007/s13167-020-00201-6.

28. Luc K, Schramm-Luc A, Guzik TJ, Mikolajczyk TP. Oxidative stress and inflammatory markers in prediabetes and diabetes. $\mathrm{J}$ Physiol Pharmacol Off J Pol Physiol Soc. 2019;70:61-8. https:// doi.org/10.26402/jpp.2019.6.01.

29. Sharma VK, Singh TG. Chronic stress and diabetes mellitus: interwoven pathologies. Curr Diabetes Rev. 2020;16:546-56. https://doi.org/10.2174/1573399815666191111152248.

30. George AK, Majumder A, Ice H, Homme RP, Eyob W, Tyagi SC, et al. Genes and genetics in hyperhomocysteinemia and the "1carbon metabolism": implications for retinal structure and eye functions. Can J Physiol Pharmacol. 2020;98:51-60. https://doi. org/10.1139/cjpp-2019-0236.

31. Zheng Z, Liu L, Zhou K, Ding L, Zeng J, Zhang W. Anti-oxidant and anti-endothelial dysfunctional properties of nano-selenium in vitro and in vivo of hyperhomocysteinemic rats. Int $\mathrm{J}$ Nanomedicine. 2020;15:4501-21. https://doi.org/10.2147/IJN. S255392.

32. Gulanski BI, Flannery CA, Peter PR, Leone CA, Stachenfeld NS. Compromised endothelial function in transgender men taking testosterone. Clin Endocrinol. 2020;92:138-44. https://doi.org/10. 1111/cen.14132.

33. El-Hafidi M, Correa F, Zazueta C. Mitochondrial dysfunction in metabolic and cardiovascular diseases associated with cardiolipin remodeling. Biochim Biophys Acta Mol basis Dis. 1866;2020: 165744. https://doi.org/10.1016/j.bbadis.2020.165744.

34. Avishai E, Golubnitschaja O. Flammer syndrome in the context of healing impairments - facts and hypotheses for multi-professional consideration. In: Golubnitschaja O, editor. Flammer Syndrome: From Phenotype to Associated Pathologies, Prediction, Prevention and Personalisation. Cham: Advances in Predictive, Preventive and Personalised Medicine; Springer International Publishing; 2019. p. 193-203. ISBN 978-3-030-13550-8.

35. Eells JT. Mitochondrial dysfunction in the aging retina. Biology. 2019;8:31. https://doi.org/10.3390/biology8020031.

36. Simon DK, Tanner CM, Brundin P. Parkinson disease epidemiology, pathology, genetics, and pathophysiology. Clin Geriatr Med. 2020;36:1-12. https://doi.org/10.1016/j.cger.2019.08.002.

37. Zeng W, Wang W, Wu S, Zhu X, Zheng T, Chen X, et al. Mitochondria and autophagy dysfunction in glucocorticoidinduced ocular hypertension/glaucoma mice model. Curr Eye Res. 2020;45:190-8. https://doi.org/10.1080/02713683.2019. 1657462 .

38. Cebioglu M, Schild HH, Golubnitschaja O. Cancer predisposition in diabetics: risk factors considered for predictive diagnostics and targeted preventive measures. EPMA J. 2010;1:130-7. https://doi. org/10.1007/s13167-010-0015-4.

39. Golubnitschaja O. Cell cycle checkpoints: the role and evaluation for early diagnosis of senescence, cardiovascular, cancer, and neurodegenerative diseases. Amino Acids. 2007;32:359-71. https:// doi.org/10.1007/s00726-006-0473-0.

40. Golubnitschaja O. Feeling cold and other underestimated symptoms in breast cancer: anecdotes or individual profiles for advanced patient stratification? EPMA J. 2017;8:17-22. https://doi. org/10.1007/s13167-017-0086-6.

41. Whitehall JC, Greaves LC. Aberrant mitochondrial function in ageing and cancer. Biogerontology. 2020;21:445-59. https://doi. org/10.1007/s10522-019-09853-y.
42. Chiu HY, Tay EXY, Ong DST, Taneja R. Mitochondrial dysfunction at the center of cancer therapy. Antioxid Redox Signal. 2020;32:309-30. https://doi.org/10.1089/ars.2019.7898.

43. Kamel K, Farrell M, O'Brien C. Mitochondrial dysfunction in ocular disease: focus on glaucoma. Mitochondrion. 2017;35:44 53. https://doi.org/10.1016/j.mito.2017.05.004.

44. Lin C-C, Tsai M-C, Lee C-T, Sun M-H, Huang T-L. Antidepressant treatment increased serum miR-183 and miR212 levels in patients with major depressive disorder. Psychiatry Res. 2018;270:232-7. https://doi.org/10.1016/j.psychres.2018. 09.025 .

45. Gheysarzadeh A, Sadeghifard N, Afraidooni L, Pooyan F, Mofid MR, Valadbeigi H, et al. Serum-based microRNA biomarkers for major depression: MiR-16, miR-135a, and miR-1202. J Res Med Sci Off J Isfahan Univ Med Sci. 2018;23:69. https://doi.org/10. 4103/jrms.JRMS 879 17.

46. Zhang H, Liu X, Chen J, Cheng K, Bai S-J, Zheng P, et al. Circulating microRNA 134 sheds light on the diagnosis of major depressive disorder. Transl Psychiatry. 2020;10:1-9. https://doi. org/10.1038/s41398-020-0773-2.

47. Roy B, Dunbar M, Shelton RC, Dwivedi Y. Identification of microRNA-124-3p as a putative epigenetic signature of major depressive disorder. Neuropsychopharmacology. 2017;42:864 75. https://doi.org/10.1038/npp.2016.175.

48. Camkurt MA, Acar Ș, Coșkun S, Güneș M, Güneș S, Y1lmaz MF, et al. Comparison of plasma MicroRNA levels in drug naive, first episode depressed patients and healthy controls. J Psychiatr Res. 2015;69:67-71. https://doi.org/10.1016/j.jpsychires.2015.07.023.

49. Wan Y, Liu Y, Wang X, Wu J, Liu K, Zhou J, et al. Identification of differential microRNAs in cerebrospinal fluid and serum of patients with major depressive disorder. PLoS One. 2015;10: e0121975. https://doi.org/10.1371/journal.pone.0121975.

50. Wang X, Sundquist K, Hedelius A, Palmér K, Memon AA, Sundquist J. Circulating microRNA-144-5p is associated with depressive disorders. Clin Epigenetics. 2015;7:69. https://doi.org/ 10.1186/s13148-015-0099-8.

51. Balakathiresan NS, Chandran R, Bhomia M, Jia M, Li H, Maheshwari RK. Serum and amygdala microRNA signatures of posttraumatic stress: fear correlation and biomarker potential. J Psychiatr Res. 2014;57:65-73. https://doi.org/10.1016/j. jpsychires.2014.05.020.

52. Lee MY, Baxter D, Scherler K, Kim T-K, Wu X, Abu-Amara D, et al. Distinct profiles of cell-free microRNAs in plasma of veterans with post-traumatic stress disorder. J Clin Med. 2019:8. https://doi.org/10.3390/jcm8070963.

53. Martin CG, Kim H, Yun S, Livingston W, Fetta J, Mysliwiec V, et al. Circulating miRNA associated with posttraumatic stress disorder in a cohort of military combat veterans. Psychiatry Res. 2017;251:261-5. https://doi.org/10.1016/j.psychres.2017.01.081.

54. Chen RJ, Kelly G, Sengupta A, Heydendael W, Nicholas B, Beltrami S, et al. MicroRNAs as biomarkers of resilience or vulnerability to stress. Neuroscience. 2015;305:36-48. https://doi. org/10.1016/j.neuroscience.2015.07.045.

55. Trumpff C, Marsland AL, Basualto-Alarcón C, Martin JL, Carroll JE, Sturm G, et al. Acute psychological stress increases serum circulating cell-free mitochondrial DNA. Psychoneuroendocrinology. 2019;106:268-76. https://doi.org/ 10.1016/j.psyneuen.2019.03.026.

56. Lindqvist D, Wolkowitz OM, Picard M, Ohlsson L, Bersani FS, Fernström J, et al. Circulating cell-free mitochondrial DNA, but not leukocyte mitochondrial DNA copy number, is elevated in major depressive disorder. Neuropsychopharmacology. 2018;43: 1557-64. https://doi.org/10.1038/s41386-017-0001-9.

57. Caspersen CJ, Powell KE, Christenson GM. Physical activity, exercise, and physical fitness: definitions and distinctions for health-related research. Public Health Rep. 1985;100:126-31. 
58. Pate RR. Physical activity and public health: a recommendation from the Centers for Disease Control and Prevention and the American College of Sports Medicine. JAMA. 1995;273:402. https://doi.org/10.1001/jama.1995.03520290054029.

59. Mota MP, Peixoto FM, Soares JF, Figueiredo PA, Leitão JC, Gaivão I, et al. Influence of aerobic fitness on age-related lymphocyte DNA damage in humans: relationship with mitochondria respiratory chain and hydrogen peroxide production. Age. 2010;32:337-46. https://doi.org/10.1007/s11357-010-9138-8.

60. Atamaniuk J, Stuhlmeier KM, Vidotto C, Tschan H, DossenbachGlaninger A, Mueller MM. Effects of ultra-marathon on circulating DNA and mRNA expression of pro- and anti-apoptotic genes in mononuclear cells. Eur J Appl Physiol. 2008;104:711-7. https://doi.org/10.1007/s00421-008-0827-2.

61. Atamaniuk J, Vidotto C, Kinzlbauer M, Bachl N, Tiran B, Tschan H. Cell-free plasma DNA and purine nucleotide degradation markers following weightlifting exercise. Eur J Appl Physiol. 2010;110:695-701. https://doi.org/10.1007/s00421-010-1532-5.

62. Atamaniuk J, Vidotto C, Tschan H, Bachl N, Stuhlmeier KM, Müller MM. Increased concentrations of cell-free plasma DNA after exhaustive exercise. Clin Chem. 2004;50:1668-70. https:// doi.org/10.1373/clinchem.2004.034553.

63. Velders M, Treff G, Machus K, Bosnyák E, Steinacker J, Schumann U. Exercise is a potent stimulus for enhancing circulating DNase activity. Clin Biochem. 2014;47:471-4. https://doi. org/10.1016/j.clinbiochem.2013.12.017.

64. Fatouros IG, Jamurtas AZ, Nikolaidis MG, Destouni A, Michailidis Y, Vrettou C, et al. Time of sampling is crucial for measurement of cell-free plasma DNA following acute aseptic inflammation induced by exercise. Clin Biochem. 2010;43: 1368-70. https://doi.org/10.1016/j.clinbiochem.2010.08.020.

65. Haller N, Tug S, Breitbach S, Jörgensen A, Simon P. Increases in circulating cell-free DNA during aerobic running depend on intensity and duration. Int J Sports Physiol Perform. 2017;12:45562. https://doi.org/10.1123/ijspp.2015-0540.

66. Fatouros IG, Destouni A, Margonis K, Jamurtas AZ, Vrettou C, Kouretas D, et al. Cell-free plasma DNA as a novel marker of aseptic inflammation severity related to exercise overtraining. Clin Chem. 2006;52:1820-4. https://doi.org/10.1373/clinchem. 2006.070417.

67. Ferrandi PJ, Fico BG, Whitehurst M, Zourdos MC, Bao F, Dodge $\mathrm{KM}$, et al. Acute high-intensity interval exercise induces comparable levels of circulating cell-free DNA and Interleukin-6 in obese and normal-weight individuals. Life Sci. 2018;202:161-6. https://doi.org/10.1016/j.lfs.2018.04.007.

68. Schlütter JM, Hatt L, Bach C, Kirkegaard I, Kølvraa S, Uldbjerg $\mathrm{N}$. The cell-free fetal DNA fraction in maternal blood decreases after physical activity. Prenat Diagn. 2014;34:341-4. https://doi. org/10.1002/pd.4306.

69. Becker C, Schmidt S, Neuberger EWI, Kirsch P, Simon P, Dettweiler U. Children's cortisol and cell-free DNA trajectories in relation to sedentary behavior and physical activity in school: a pilot study. Front Public Health. 2019;7. https://doi.org/10.3389/ fpubh.2019.00026.

70. Párrizas M, Brugnara L, Esteban Y, González-Franquesa A, Canivell S, Murillo S, et al. Circulating miR-192 and miR-193b are markers of prediabetes and are modulated by an exercise intervention. J Clin Endocrinol Metab. 2015;100:E407-15. https:// doi.org/10.1210/jc.2014-2574.

71. de Gonzalo-Calvo D, Dávalos A, Fernández-Sanjurjo M, AmadoRodríguez L, Díaz-Coto S, Tomás-Zapico $\mathrm{C}$, et al. Circulating microRNAs as emerging cardiac biomarkers responsive to acute exercise. Int J Cardiol. 2018;264:130-6. https://doi.org/10.1016/j. ijcard.2018.02.092.

72. Bao F, Slusher AL, Whitehurst M, Huang C-J. Circulating microRNAs are upregulated following acute aerobic exercise in obese individuals. Physiol Behav. 2018;197:15-21. https://doi. org/10.1016/j.physbeh.2018.09.011.

73. Fekadu G, Chelkeba L, Melaku T, Tegene E, Kebede A. 30-day and 60-day rates and predictors of mortality among adult stroke patients: prospective cohort study. Ann Med Surg. 2020;53:1-11. https://doi.org/10.1016/j.amsu.2020.03.001.

74. Stanzione R, Cotugno M, Bianchi F, Marchitti S, Forte M, Volpe $\mathrm{M}$, et al. Pathogenesis of ischemic stroke: role of epigenetic mechanisms. Genes. 2020;11. https://doi.org/10.3390/genes11010089.

75. Donkor ES. Stroke in the 21st century: a snapshot of the burden, epidemiology, and quality of life. Stroke Res Treat. 2018;2018. https://doi.org/10.1155/2018/3238165.

76. Zoghi A, Petramfar P, Nikseresht A, Sakhaee E. Investigation of ischemic and demyelinating lesions by cerebral vasoreactivity based on transcranial Doppler sonography: a comparative study. Neuropsychiatr Dis Treat. 2018;14:2323-8. https://doi.org/10. 2147/NDT.S150062.

77. Vajpeyee A, Wijatmiko T, Vajpeyee M, Taywade O, Pandey S, Chauhan PS. Clinical usefulness of cell-free DNA as a prognostic marker in acute ischemic stroke. Neurologist. 2020;25:11-3. https://doi.org/10.1097/NRL.0000000000000249.

78. Wijerathne H, Witek MA, Baird AE, Soper SA. Liquid biopsy markers for stroke diagnosis. Expert Rev Mol Diagn. 2020:118. https://doi.org/10.1080/14737159.2020.1777859.

79. Rothstein L, Jickling GC. Ischemic stroke biomarkers in blood. Biomark Med. 2013;7:37-47. https://doi.org/10.2217/bmm.12. 104.

80. Wang W, Li D-B, Li R-Y, Zhou X, Yu D-J, Lan X-Y, et al. Diagnosis of hyperacute and acute ischaemic stroke: the potential utility of exosomal microRNA-21-5p and microRNA-30a-5p. Cerebrovasc Dis Basel Switz. 2018;45:204-12. https://doi.org/ $10.1159 / 000488365$.

81. Vajpeyee A, Wijatmiko T, Vajpeyee M, Taywade O. Cell free DNA: a novel predictor of neurological outcome after intravenous thrombolysis and/or mechanical thrombectomy in acute ischemic stroke patients. Neurointervention. 2018;13:13-9. https://doi.org/ 10.5469/neuroint.2018.13.1.13.

82. Tsai N-W, Lin T-K, Chen S-D, Chang W-N, Wang H-C, Yang T$\mathrm{M}$, et al. The value of serial plasma nuclear and mitochondrial DNA levels in patients with acute ischemic stroke. Clin Chim Acta Int J Clin Chem. 2011;412:476-9. https://doi.org/10.1016/j. cca.2010.11.036.

83. Cui X, Du S, Liu H, Liu J, Wu Q, Huo Q, et al. The length and distribution of plasma cell-free DNA fragments in stroke patients. Biomed Res Int. 2020;2020:9054196. https://doi.org/10.1155/ 2020/9054196.

84. Chen Y, Song Y, Huang J, Qu M, Zhang Y, Geng J, et al. Increased circulating exosomal miRNA-223 is associated with acute ischemic stroke. Front Neurol. 2017;8:57. https://doi.org/ 10.3389/fneur.2017.00057.

85. Wang Y, Ma Z, Kan P, Zhang B. The diagnostic value of serum miRNA-221-3p, miRNA-382-5p, and miRNA-4271 in ischemic stroke. J. Stroke Cerebrovasc. Dis. Off. J Natl Stroke Assoc. 2017;26:1055-60. https://doi.org/10.1016/j.jstrokecerebrovasdis. 2016.12.019.

86. Vijayan M, Kumar S, Yin X, Zafer D, Chanana V, Cengiz P, et al. Identification of novel circulatory microRNA signatures linked to patients with ischemic stroke. Hum Mol Genet. 2018;27:2318-29. https://doi.org/10.1093/hmg/ddy136.

87. Cantalupo PG, Katz JP, Pipas JM. Viral sequences in human cancer. Virology. 2018;513:208-16. https://doi.org/10.1016/j.virol. 2017.10.017.

88. Adjorlolo-Johnson G, Unger ER, Boni-Ouattara E, TouréCoulibaly K, Maurice C, Vernon SD, et al. Assessing the relationship between HIV infection and cervical cancer in Côte d'Ivoire: a 
case-control study. BMC Infect Dis. 2010;10:242. https://doi.org/ 10.1186/1471-2334-10-242.

89. Gu Y, Wan C, Qiu J, Cui Y, Jiang T, Zhuang Z. Circulating HPV cDNA in the blood as a reliable biomarker for cervical cancer: a meta-analysis. PLoS One. 2020;15:e0224001. https://doi.org/10. 1371/journal.pone.0224001.

90. Tang K-W, Alaei-Mahabadi B, Samuelsson T, Lindh M, Larsson E. The landscape of viral expression and host gene fusion and adaptation in human cancer. Nat Commun. 2013;4:2513. https:// doi.org/10.1038/ncomms3513.

91. Giráldez MD, Lozano JJ, Ramírez G, Hijona E, Bujanda L, Castells A, et al. Circulating microRNAs as biomarkers of colorectal cancer: results from a genome-wide profiling and validation study. Clin Gastroenterol Hepatol Off Clin Pract J Am Gastroenterol Assoc. 2013;11:681-688.e3. https://doi.org/10. 1016/j.cgh.2012.12.009.

92. Sharova E, Grassi A, Marcer A, Ruggero K, Pinto F, Bassi P, et al. A circulating miRNA assay as a first-line test for prostate cancer screening. Br J Cancer. 2016;114:1362-6. https://doi.org/10. 1038/bjc.2016.151.

93. Sánchez BE, Aguayo A, Martínez B, Rodríguez F, Marmolejo M, Svyryd Y, et al. Using genetic and epigenetic markers to improve differential diagnosis of prostate cancer and benign prostatic hyperplasia by noninvasive methods in Mexican patients. Clin Genitourin Cancer. 2018;16:e867-77. https://doi.org/10.1016/j. clgc.2018.02.004.

94. Frattini M, Gallino G, Signoroni S, Balestra D, Lusa L, Battaglia $\mathrm{L}$, et al. Quantitative and qualitative characterization of plasma DNA identifies primary and recurrent colorectal cancer. Cancer Lett. 2008;263:170-81. https://doi.org/10.1016/j.canlet.2008.03. 021.

95. Heitzer E, Auer M, Hoffmann EM, Pichler M, Gasch C, Ulz P, et al. Establishment of tumor-specific copy number alterations from plasma DNA of patients with cancer. Int J Cancer. 2013;133:346-56. https://doi.org/10.1002/ijc.28030.

96. van der Vaart M, Pretorius PJ. Is the role of circulating DNA as a biomarker of cancer being prematurely overrated? Clin Biochem. 2010;43:26-36. https://doi.org/10.1016/j.clinbiochem.2009.08. 027.

97. Jahr S, Hentze H, Englisch S, Hardt D, Fackelmayer FO, Hesch $\mathrm{RD}$, et al. DNA fragments in the blood plasma of cancer patients: quantitations and evidence for their origin from apoptotic and necrotic cells. Cancer Res. 2001;61:1659-65.

98. Diehl F, Li M, Dressman D, He Y, Shen D, Szabo S, et al. Detection and quantification of mutations in the plasma of patients with colorectal tumors. Proc Natl Acad Sci U S A. 2005;102: 16368-73. https://doi.org/10.1073/pnas.0507904102.

99. Sikora K, Bedin C, Vicentini C, Malpeli G, D’Angelo E, Sperandio N, et al. Evaluation of cell-free DNA as a biomarker for pancreatic malignancies. Int J Biol Markers. 2015;30:136-41. https://doi.org/10.5301/jbm.5000088.

100. Stroun M, Lyautey J, Lederrey C, Mulcahy HE, Anker P. Alu repeat sequences are present in increased proportions compared to a unique gene in plasma/serum DNA: evidence for a preferential release from viable cells? Ann N Y Acad Sci. 2001;945:25864. https://doi.org/10.1111/j.1749-6632.2001.tb03894.x.

101. Desai A, Kallianpur S, Mani A, Tijare MS, Khan S, Jain M, et al. Quantification of circulating plasma cell free DNA fragments in patients with oral cancer and precancer. Gulf J Oncolog. 2018;1: 11-7.

102. Phallen J, Sausen M, Adleff V, Leal A, Hruban C, White J, et al. Direct detection of early-stage cancers using circulating tumor DNA. Sci Transl Med. 2017;9. https://doi.org/10.1126/ scitranslmed.aan2415.
103. Hussain SP, Harris CC. Inflammation and cancer: an ancient link with novel potentials. Int J Cancer. 2007;121:2373-80. https://doi. org/10.1002/ijc.23173.

104. Pinlaor S, Ma N, Hiraku Y, Yongvanit P, Semba R, Oikawa S, et al. Repeated infection with Opisthorchis viverrini induces accumulation of 8-nitroguanine and 8-oxo-7,8-dihydro-2'deoxyguanine in the bile duct of hamsters via inducible nitric oxide synthase. Carcinogenesis. 2004;25:1535-42. https://doi. org/10.1093/carcin/bgh157.

105. Ohnishi S, Ma N, Thanan R, Pinlaor S, Hammam O, Murata M, Kawanishi S. DNA Damage in Inflammation-Related Carcinogenesis and Cancer Stem Cells Available online: https:// www.hindawi.com/journals/omcl/2013/387014/ ().

106. Schetter AJ, Heegaard NHH, Harris CC. Inflammation and cancer: interweaving microRNA, free radical, cytokine and p53 pathways. Carcinogenesis. 2010;31:37-49. https://doi.org/10.1093/carcin/ bgp272.

107. Murata M. Inflammation and cancer. Environ Health Prev Med. 2018;23:50. https://doi.org/10.1186/s12199-018-0740-1.

108. Kustanovich A, Schwartz R, Peretz T, Grinshpun A. Life and death of circulating cell-free DNA. Cancer Biol Ther. 2019;20: 1057-67. https://doi.org/10.1080/15384047.2019.1598759.

109. Sfanos KS, De Marzo AM. Prostate cancer and inflammation: the evidence. Histopathology. 2012;60:199-215. https://doi.org/10. 1111/j.1365-2559.2011.04033.x.

110. Kwon O-J, Zhang L, Ittmann MM, Xin L. Prostatic inflammation enhances basal-to-luminal differentiation and accelerates initiation of prostate cancer with a basal cell origin. Proc Natl Acad Sci U S A. 2014;111:E592-600. https://doi.org/10.1073/pnas. 1318157111 .

111. Mani RS, Amin MA, Li X, Kalyana-Sundaram S, Veeneman BA, Wang L, et al. Inflammation induced oxidative stress mediates gene fusion formation in prostate cancer. Cell Rep. 2016;17: 2620-31. https://doi.org/10.1016/j.celrep.2016.11.019.

112. de Bono JS, Guo C, Gurel B, De Marzo AM, Sfanos KS, Mani RS, et al. Prostate carcinogenesis: inflammatory storms. Nat Rev Cancer. 2020;20:455-69. https://doi.org/10.1038/s41568-0200267-9.

113. Kucera R, Pecen L, Topolcan O, Dahal AR, Costigliola V, Giordano FA, et al. Prostate cancer management: long-term beliefs, epidemic developments in the early twenty-first century and 3PM dimensional solutions. EPMA J. 2020. https://doi.org/10. 1007/s13167-020-00214-1

114. Ammirante M, Luo J-L, Grivennikov S, Nedospasov S, Karin M. B cell-derived lymphotoxin promotes castration-resistant prostate cancer. Nature. 2010;464:302-5. https://doi.org/10.1038/ nature 08782

115. Garcia AJ, Ruscetti M, Arenzana TL, Tran LM, Bianci-Frias D, Sybert E, et al. Pten null prostate epithelium promotes localized myeloid-derived suppressor cell expansion and immune suppression during tumor initiation and progression. Mol Cell Biol. 2014;34:2017-28. https://doi.org/10.1128/MCB.00090-14.

116. Leibowitz-Amit R, Templeton AJ, Omlin A, Pezaro C, Atenafu EG, Keizman D, et al. Clinical variables associated with PSA response to abiraterone acetate in patients with metastatic castration-resistant prostate cancer. Ann Oncol Off J Eur Soc Med Oncol. 2014;25:657-62. https://doi.org/10.1093/annonc/ mdt581.

117. Han X, Wang J, Sun Y. Circulating tumor DNA as biomarkers for Cancer detection. Genomics Proteomics Bioinformatics. 2017;15: 59-72. https://doi.org/10.1016/j.gpb.2016.12.004.

118. Siravegna G, Mussolin B, Venesio T, Marsoni S, Seoane J, Dive $\mathrm{C}$, et al. How liquid biopsies can change clinical practice in oncology. Ann Oncol. 2019;30:1580-90. https://doi.org/10.1093/ annonc/mdz227. 
119. Stroun M, Anker P, Maurice P, Lyautey J, Lederrey C, Beljanski M. Neoplastic characteristics of the DNA found in the plasma of cancer patients. Oncology. 1989;46:318-22. https://doi.org/10. $1159 / 000226740$

120. Wu X, Li J, Gassa A, Buchner D, Alakus H, Dong Q, et al. Circulating tumor DNA as an emerging liquid biopsy biomarker for early diagnosis and therapeutic monitoring in hepatocellular carcinoma. Int J Biol Sci. 2020;16:1551-62. https://doi.org/10. 7150/ijbs.44024.

121. Li J, Han X, Yu X, Xu Z, Yang G, Liu B, et al. Clinical applications of liquid biopsy as prognostic and predictive biomarkers in hepatocellular carcinoma: circulating tumor cells and circulating tumor DNA. J Exp Clin Cancer Res CR. 2018;37:213. https://doi. org/10.1186/s13046-018-0893-1.

122. von Felden J, Craig AJ, Villanueva A. Role of circulating tumor DNA to help decision-making in hepatocellular carcinoma. Oncoscience. 2018;5:209-11. https://doi.org/10.18632/ oncoscience.446.

123. De Mattos-Arruda L, Mayor R, Ng CKY, Weigelt B, MartínezRicarte F, Torrejon D, et al. Cerebrospinal fluid-derived circulating tumour DNA better represents the genomic alterations of brain tumours than plasma. Nat Commun. 2015;6:8839. https://doi.org/ $10.1038 /$ ncomms 9839

124. Wang Y, Springer S, Mulvey CL, Silliman N, Schaefer J, Sausen $\mathrm{M}$, et al. Detection of somatic mutations and HPV in the saliva and plasma of patients with head and neck squamous cell carcinomas. Sci Transl Med. 2015;7:293ra104. https://doi.org/10.1126/ scitranslmed.aaa8507.

125. Husain H, Melnikova VO, Kosco K, Woodward B, More S, Pingle SC, et al. Monitoring daily dynamics of early tumor response to targeted therapy by detecting circulating tumor DNA in urine. Clin Cancer Res Off J Am Assoc Cancer Res. 2017;23: 4716-23. https://doi.org/10.1158/1078-0432.CCR-17-0454.

126. Siravegna G, Marsoni S, Siena S, Bardelli A. Integrating liquid biopsies into the management of cancer. Nat Rev Clin Oncol. 2017;14:531-48. https://doi.org/10.1038/nrclinonc.2017.14.

127. Marcuello M, Vymetalkova V, Neves RPL, Duran-Sanchon S, Vedeld HM, Tham E, et al. Circulating biomarkers for early detection and clinical management of colorectal cancer. Mol Asp Med. 2019;69:107-22. https://doi.org/10.1016/j.mam.2019.06. 002 .

128. Diehl F, Schmidt K, Choti MA, Romans K, Goodman S, Li M, et al. Circulating mutant DNA to assess tumor dynamics. Nat Med. 2008;14:985-90. https://doi.org/10.1038/nm.1789.

129. Dawson S-J, Tsui DWY, Murtaza M, Biggs H, Rueda OM, Chin S-F, et al. Analysis of circulating tumor DNA to monitor metastatic breast cancer. N Engl J Med. 2013;368:1199-209. https://doi. org/10.1056/NEJMoa1213261.

130. Bettegowda C, Sausen M, Leary RJ, Kinde I, Wang Y, Agrawal $\mathrm{N}$, et al. Detection of Circulating Tumor DNA in Early- and LateStage Human Malignancies. Sci Transl Med. 2014;6:224ra24. https://doi.org/10.1126/scitranslmed.3007094

131. Sozzi G, Conte D, Leon M, Ciricione R, Roz L, Ratcliffe C, et al. Quantification of free circulating DNA as a diagnostic marker in lung cancer. J Clin Oncol Off J Am Soc Clin Oncol. 2003;21: 3902-8. https://doi.org/10.1200/JCO.2003.02.006.

132. Kim K, Shin DG, Park MK, Baik SH, Kim TH, Kim S, et al. Circulating cell-free DNA as a promising biomarker in patients with gastric cancer: diagnostic validity and significant reduction of cfDNA after surgical resection. Ann Surg Treat Res. 2014;86: 136-42. https://doi.org/10.4174/astr.2014.86.3.136.

133. Chen X, Bonnefoi H, Diebold-Berger S, Lyautey J, Lederrey C, Faltin-Traub E, et al. Detecting tumor-related alterations in plasma or serum DNA of patients diagnosed with breast cancer. Clin. Cancer Res. Off. J. Am. Assoc. Cancer Res. 1999;5:2297-303.
134. Sozzi G, Conte D, Mariani L, Lo Vullo S, Roz L, Lombardo C, et al. Analysis of circulating tumor DNA in plasma at diagnosis and during follow-up of lung cancer patients. Cancer Res. 2001;61:4675-8.

135. Heitzer E, Ulz P, Geigl JB. Circulating tumor DNA as a liquid biopsy for Cancer. Clin Chem. 2015;61:112-23. https://doi.org/ 10.1373/clinchem.2014.222679.

136. Gormally E, Vineis P, Matullo G, Veglia F, Caboux E, Le Roux E, et al. TP53 and KRAS2 mutations in plasma DNA of healthy subjects and subsequent cancer occurrence: a prospective study. Cancer Res. 2006;66:6871-6. https://doi.org/10.1158/0008-5472. CAN-05-4556.

137. Madhavan D, Wallwiener M, Bents K, Zucknick M, Nees J, Schott S, et al. Plasma DNA integrity as a biomarker for primary and metastatic breast cancer and potential marker for early diagnosis. Breast Cancer Res Treat. 2014;146:163-74. https://doi.org/ 10.1007/s10549-014-2946-2.

138. Valtorta E, Misale S, Sartore-Bianchi A, Nagtegaal ID, Paraf F, Lauricella C, et al. KRAS gene amplification in colorectal cancer and impact on response to EGFR-targeted therapy. Int J Cancer. 2013;133:1259-65. https://doi.org/10.1002/ijc.28106.

139. Thierry AR, Mouliere F, El Messaoudi S, Mollevi C, LopezCrapez E, Rolet F, et al. Clinical validation of the detection of KRAS and BRAF mutations from circulating tumor DNA. Nat Med. 2014;20:430-5. https://doi.org/10.1038/nm.3511.

140. Misale S, Yaeger R, Hobor S, Scala E, Janakiraman M, Liska D, et al. Emergence of KRAS mutations and acquired resistance to anti-EGFR therapy in colorectal cancer. Nature. 2012;486:532-6. https://doi.org/10.1038/nature11156.

141. Chan KCA, Jiang P, Zheng YWL, Liao GJW, Sun H, Wong J, et al. Cancer genome scanning in plasma: detection of tumorassociated copy number aberrations, single-nucleotide variants, and tumoral heterogeneity by massively parallel sequencing. Clin Chem. 2013;59:211-24. https://doi.org/10.1373/clinchem. 2012.196014.

142. Heitzer E, Ulz P, Belic J, Gutschi S, Quehenberger F, Fischereder $\mathrm{K}$, et al. Tumor-associated copy number changes in the circulation of patients with prostate cancer identified through whole-genome sequencing. Genome Med. 2013;5:30. https://doi.org/10.1186/ gm434.

143. Beaver JA, Jelovac D, Balukrishna S, Cochran R, Croessmann S, Zabransky DJ, et al. Detection of cancer DNA in plasma of patients with early-stage breast cancer. Clin Cancer Res Off J Am Assoc Cancer Res. 2014;20:2643-50. https://doi.org/10.1158/ 1078-0432.CCR-13-2933.

144. Klco JM, Miller CA, Griffith M, Petti A, Spencer DH, KetkarKulkarni S, et al. Association between mutation clearance after induction therapy and outcomes in acute myeloid leukemia. JAMA. 2015;314:811-22. https://doi.org/10.1001/jama.2015. 9643.

145. Reinert T, Schøler LV, Thomsen R, Tobiasen H, Vang S, Nordentoft I, et al. Analysis of circulating tumour DNA to monitor disease burden following colorectal cancer surgery. Gut. 2016;65:625-34. https://doi.org/10.1136/gutjnl-2014-308859.

146. Tie J, Wang Y, Tomasetti C, Li L, Springer S, Kinde I, et al. Circulating tumor DNA analysis detects minimal residual disease and predicts recurrence in patients with stage II colon cancer. Sci Transl Med. 2016;8:346ra92. https://doi.org/10.1126/ scitranslmed.aaf6219.

147. Pécuchet N, Zonta E, Didelot A, Combe P, Thibault C, Gibault L, et al. Base-position error rate analysis of next-generation sequencing applied to circulating tumor DNA in non-small cell lung cancer: a prospective study. PLoS Med. 2016;13:e1002199. https:// doi.org/10.1371/journal.pmed.1002199.

148. Lecomte T, Berger A, Zinzindohoué F, Micard S, Landi B, Blons $\mathrm{H}$, et al. Detection of free-circulating tumor-associated DNA in 
plasma of colorectal cancer patients and its association with prognosis. Int J Cancer. 2002;100:542-8. https://doi.org/10.1002/ijc. 10526.

149. Spindler K-LG, Pallisgaard N, Vogelius I, Jakobsen A. Quantitative cell-free DNA, KRAS, and BRAF mutations in plasma from patients with metastatic colorectal cancer during treatment with cetuximab and irinotecan. Clin Cancer Res Off J Am Assoc Cancer Res. 2012;18:1177-85. https://doi.org/10.1158/ 1078-0432.CCR-11-0564.

150. Punnoose EA, Atwal S, Liu W, Raja R, Fine BM, Hughes BGM, et al. Evaluation of circulating tumor cells and circulating tumor DNA in non-small cell lung cancer: association with clinical endpoints in a phase II clinical trial of pertuzumab and erlotinib. Clin Cancer Res Off J Am Assoc Cancer Res. 2012;18:2391-401. https://doi.org/10.1158/1078-0432.CCR-11-3148.

151. Bidard F-C, Madic J, Mariani P, Piperno-Neumann S, Rampanou A, Servois V, et al. Detection rate and prognostic value of circulating tumor cells and circulating tumor DNA in metastatic uveal melanoma. Int J Cancer. 2014;134:1207-13. https://doi.org/10. 1002/ijc.28436.

152. Ng EKO, Chong WWS, Jin H, Lam EKY, Shin VY, Yu J, et al. Differential expression of microRNAs in plasma of patients with colorectal cancer: a potential marker for colorectal cancer screening. Gut. 2009;58:1375-81. https://doi.org/10.1136/gut.2008. 167817.

153. Herreros-Villanueva M, Duran-Sanchon S, Martín AC, PérezPalacios R, Vila-Navarro E, Marcuello M, et al. Plasma microRNA signature validation for early detection of colorectal cancer. Clin Transl Gastroenterol. 2019;10:e00003. https://doi. org/10.14309/ctg.0000000000000003.

154. Zhang G-J, Zhou T, Liu Z-L, Tian H-P, Xia S-S. Plasma miR$200 \mathrm{c}$ and miR-18a as potential biomarkers for the detection of colorectal carcinoma. Mol Clin Oncol. 2013;1:379-84. https:// doi.org/10.3892/mco.2013.61.

155. Zekri A-RN, Youssef ASE-D, Lotfy MM, Gabr R, Ahmed OS, Nassar A, et al. Circulating serum miRNAs as diagnostic markers for colorectal cancer. PLoS One. 2016;11:e0154130. https://doi. org/10.1371/journal.pone.0154130.

156. Liu T, Yin L, Yan G, Li C, Wang L. A meta-analysis of microRNA-17 as a potential biomarker in diagnosis of colorectal cancer. Cell Mol Biol Noisy-Gd Fr. 2018;64:86-93.

157. Liu G-H, Zhou Z-G, Chen R, Wang M-J, Zhou B, Li Y, et al. Serum miR-21 and miR-92a as biomarkers in the diagnosis and prognosis of colorectal cancer. Tumour Biol J Int Soc Oncodev Biol Med. 2013;34:2175-81. https://doi.org/10.1007/s13277-0130753-8.

158. Huang Z, Huang D, Ni S, Peng Z, Sheng W, Du X. Plasma microRNAs are promising novel biomarkers for early detection of colorectal cancer. Int J Cancer. 2010;127:118-26. https://doi. org/10.1002/ijc. 25007 .

159. Kanaan Z, Rai SN, Eichenberger MR, Roberts H, Keskey B, Pan $\mathrm{J}$, et al. Plasma miR-21: a potential diagnostic marker of colorectal cancer. Ann Surg. 2012;256:544-51. https://doi.org/10.1097/ SLA.0b013e318265bd6f.

160. Zhu M, Huang Z, Zhu D, Zhou X, Shan X, Qi L, et al. A panel of microRNA signature in serum for colorectal cancer diagnosis. Oncotarget. 2017;8:17081-91. https://doi.org/10.18632/ oncotarget.15059.

161. Wikberg ML, Myte R, Palmqvist R, van Guelpen B, Ljuslinder I. Plasma miRNA can detect colorectal cancer, but how early? Cancer Med. 2018;7:1697-705. https://doi.org/10.1002/cam4. 1398.

162. Matsumura T, Sugimachi K, Iinuma H, Takahashi Y, Kurashige J, Sawada G, et al. Exosomal microRNA in serum is a novel biomarker of recurrence in human colorectal cancer. $\mathrm{Br} \mathrm{J}$ Cancer. 2015;113:275-81. https://doi.org/10.1038/bjc.2015.201.
163. Ogata-Kawata H, Izumiya M, Kurioka D, Honma Y, Yamada Y, Furuta K, et al. Circulating exosomal microRNAs as biomarkers of colon cancer. PLoS One. 2014;9:e92921. https://doi.org/10. 1371/journal.pone.0092921.

164. Chan M, Liaw CS, Ji SM, Tan HH, Wong CY, Thike AA, et al Identification of circulating microRNA signatures for breast cancer detection. Clin Cancer Res Off J Am Assoc Cancer Res. 2013;19:4477-87. https://doi.org/10.1158/1078-0432.CCR-123401

165. Wang P-Y, Gong H-T, Li B-F, Lv C-L, Wang H-T, Zhou H-H, et al. Higher expression of circulating miR-182 as a novel biomarker for breast cancer. Oncol Lett. 2013;6:1681-6. https://doi. org/10.3892/ol.2013.1593.

166. Cuk K, Zucknick M, Heil J, Madhavan D, Schott S, Turchinovich A, et al. Circulating microRNAs in plasma as early detection markers for breast cancer. Int J Cancer. 2013;132:1602-12. https://doi.org/10.1002/ijc.27799.

167. Eichelser C, Flesch-Janys D, Chang-Claude J, Pantel K, Schwarzenbach H. Deregulated serum concentrations of circulating cell-free microRNAs miR-17, miR-34a, miR-155, and miR373 in human breast cancer development and progression. Clin Chem. 2013;59:1489-96. https://doi.org/10.1373/clinchem.2013. 205161.

168. Kumar S, Keerthana R, Pazhanimuthu A, Perumal P. Overexpression of circulating miRNA-21 and miRNA-146a in plasma samples of breast cancer patients. Indian J Biochem Biophys. 2013;50:210-4.

169. Mar-Aguilar F, Mendoza-Ramírez JA, Malagón-Santiago I, Espino-Silva PK, Santuario-Facio SK, Ruiz-Flores P, et al. Serum circulating microRNA profiling for identification of potential breast cancer biomarkers. Dis Markers. 2013;34:163-9. https://doi.org/10.3233/DMA-120957.

170. Si H, Sun X, Chen Y, Cao Y, Chen S, Wang H, et al. Circulating microRNA-92a and microRNA-21 as novel minimally invasive biomarkers for primary breast cancer. J Cancer Res Clin Oncol. 2013;139:223-9. https://doi.org/10.1007/s00432-012-1315-y.

171. Asaga S, Kuo C, Nguyen T, Terpenning M, Giuliano AE, Hoon DS. Direct serum assay for microRNA-21 concentrations in early and advanced breast cancer. Clin Chem. 2011;57:84-91. https:// doi.org/10.1373/clinchem.2010.151845.

172. Schrauder MG, Strick R, Schulz-Wendtland R, Strissel PL, Kahmann L, Loehberg CR, et al. Circulating micro-RNAs as potential blood-based markers for early stage breast cancer detection. PLoS One. 2012;7:e29770. https://doi.org/10.1371/journal.pone. 0029770.

173. Ng EKO, Li R, Shin VY, Jin HC, Leung CPH, Ma ESK, et al. Circulating microRNAs as specific biomarkers for breast cancer detection. PLoS One. 2013;8:e53141. https://doi.org/10.1371/ journal.pone.0053141.

174. Foss KM, Sima C, Ugolini D, Neri M, Allen KE, Weiss GJ. miR1254 and miR-574-5p: serum-based microRNA biomarkers for early-stage non-small cell lung cancer. J Thorac Oncol Off Publ Int Assoc Study Lung Cancer. 2011;6:482-8. https://doi.org/10. 1097/JTO.0b013e318208c785.

175. Chen X, Hu Z, Wang W, Ba Y, Ma L, Zhang C, et al. Identification of ten serum microRNAs from a genome-wide serum microRNA expression profile as novel noninvasive biomarkers for nonsmall cell lung cancer diagnosis. Int $\mathrm{J}$ Cancer. 2012;130:1620-8. https://doi.org/10.1002/ijc.26177.

176. Bianchi F, Nicassio F, Marzi M, Belloni E, Dall'olio V, Bernard $\mathrm{L}$, et al. A serum circulating miRNA diagnostic test to identify asymptomatic high-risk individuals with early stage lung cancer. EMBO Mol Med. 2011;3:495-503. https://doi.org/10.1002/ emmm.201100154.

177. Wang ZX, Bian HB, Wang JR, Cheng ZX, Wang KM, De W. Prognostic significance of serum miRNA-21 expression in human 
non-small cell lung cancer. J Surg Oncol. 2011;104:847-51. https://doi.org/10.1002/jso.22008.

178. Hu Z, Chen X, Zhao Y, Tian T, Jin G, Shu Y, et al. Serum microRNA signatures identified in a genome-wide serum microRNA expression profiling predict survival of non-smallcell lung cancer. J Clin Oncol Off J Am Soc Clin Oncol. 2010;28:1721-6. https://doi.org/10.1200/JCO.2009.24.9342.

179. Zheng D, Haddadin S, Wang Y, Gu L-Q, Perry MC, Freter CE, et al. Plasma microRNAs as novel biomarkers for early detection of lung cancer. Int J Clin Exp Pathol. 2011;4:575-86.

180. Boeri M, Verri C, Conte D, Roz L, Modena P, Facchinetti F, et al. MicroRNA signatures in tissues and plasma predict development and prognosis of computed tomography detected lung cancer. Proc Natl Acad Sci U S A. 2011;108:3713-8. https://doi.org/10. 1073/pnas.1100048108.

181. Shen J, Todd NW, Zhang H, Yu L, Lingxiao X, Mei Y, et al. Plasma microRNAs as potential biomarkers for non-small-cell lung cancer. Lab Investig J Tech Methods Pathol. 2011;91:57987. https://doi.org/10.1038/labinvest.2010.194.

182. Yang Y, Hu Z, Zhou Y, Zhao G, Lei Y, Li G, et al. The clinical use of circulating microRNAs as non-invasive diagnostic biomarkers for lung cancers. Oncotarget. 2017;8:90197-214. https://doi.org/ 10.18632/oncotarget.21644.

183. Al-Kafaji G, Al-Naieb ZT, Bakhiet M. Increased oncogenic microRNA-18a expression in the peripheral blood of patients with prostate cancer: a potential novel non-invasive biomarker. Oncol Lett. 2016;11:1201-6. https://doi.org/10.3892/ol.2015.4014.

184. Mitchell PS, Parkin RK, Kroh EM, Fritz BR, Wyman SK, Pogosova-Agadjanyan EL, et al. Circulating microRNAs as stable blood-based markers for cancer detection. Proc Natl Acad Sci. 2008;105:10513-8. https://doi.org/10.1073/pnas.0804549105.

185. Bidarra D, Constâncio V, Barros-Silva D, Ramalho-Carvalho J, Moreira-Barbosa C, Antunes L, et al. Circulating microRNAs as biomarkers for prostate Cancer detection and metastasis development prediction. Front Oncol. 2019;9. https://doi.org/10.3389/ fonc.2019.00900

186. Kong X, Qian X, Duan L, Liu H, Zhu Y, Qi J. microRNA-372 suppresses migration and invasion by targeting p65 in human prostate cancer cells. DNA Cell Biol. 2016;35:828-35. https:// doi.org/10.1089/dna.2015.3186.

187. Ha T-Y. MicroRNAs in human diseases: from cancer to cardiovascular disease. Immune Netw. 2011;11:135-54. https://doi.org/ 10.4110/in.2011.11.3.135.

188. Shenouda SK, Alahari SK. MicroRNA function in cancer: oncogene or a tumor suppressor? Cancer Metastasis Rev. 2009;28:369. https://doi.org/10.1007/s10555-009-9188-5.

189. Esquela-Kerscher A, Slack FJ. Oncomirs - microRNAs with a role in cancer. Nat Rev Cancer. 2006;6:259-69. https://doi.org/ $10.1038 / \mathrm{nrc} 1840$

190. Meyerson M, Carbone D. Genomic and proteomic profiling of lung cancers: lung cancer classification in the age of targeted therapy. J Clin Oncol Off J Am Soc Clin Oncol. 2005;23:3219-26. https://doi.org/10.1200/JCO.2005.15.511.

191. Sato T, Baskoro H, Rennard SI, Seyama K, Takahashi K. MicroRNAs as therapeutic targets in lung disease: prospects and challenges. Chronic Obstr Pulm Dis. 3:382-8. https://doi.org/10. 15326/jcopdf.3.1.2015.0160.

192. Diamandis EP. Prostate Cancer screening with prostate-specific antigen testing: More answers or More confusion? Clin Chem. 2010;56:345-51. https://doi.org/10.1373/clinchem.2009.140046.

193. Calin GA, Croce CM. MicroRNA signatures in human cancers. Nat Rev Cancer. 2006;6:857-66. https://doi.org/10.1038/nrc1997.
194. Vanacore D, Boccellino M, Rossetti S, Cavaliere C, D’Aniello C, Di Franco R, et al. Micrornas in prostate cancer: an overview. Oncotarget. 2017;8:50240-51. https://doi.org/10.18632/oncotarget.16933.

195. Xu MJ, Dorsey JF, Amaravadi R, Karakousis G, Simone CB, Xu $\mathrm{X}$, et al. Circulating tumor cells, DNA, and mRNA: potential for clinical utility in patients with melanoma. Oncologist. 2016;21: 84-94. https://doi.org/10.1634/theoncologist.2015-0207.

196. Zhang Z, Lanz RB, Xiao L, Wang L, Hartig SM, Ittmann MM, et al. The tumor suppressive miR-200b subfamily is an ERG target gene in human prostate tumors. Oncotarget. 2016;7:37993-8003. https://doi.org/10.18632/oncotarget.9366.

197. Kharroubi AT, Darwish HM. Diabetes mellitus: the epidemic of the century. World J Diabetes. 2015;6:850-67. https://doi.org/10. 4239/wjd.v6.i6.850.

198. Zhang K, Lin G, Han Y, Xie J, Li J. Circulating unmethylated insulin DNA as a potential non-invasive biomarker of beta cell death in type 1 diabetes: a review and future prospect. Clin Epigenetics. 2017;9:44. https://doi.org/10.1186/s13148-017-0343-5.

199. Abudawood M. Diabetes and cancer: a comprehensive review. J Res Med Sci Off J Isfahan Univ Med Sci. 2019;24:94. https://doi. org/10.4103/jrms.JRMS_242_19.

200. Giovannucci E, Harlan DM, Archer MC, Bergenstal RM, Gapstur SM, Habel LA, et al. Diabetes and cancer: a consensus report. Diabetes Care. 1674-1685;2010:33. https://doi.org/10.2337/ dc10-0666.

201. Lee SC, Chan JCN. Evidence for DNA damage as a biological link between diabetes and cancer. Chin Med J. 2015;128:1543-8. https://doi.org/10.4103/0366-6999.157693.

202. Zelenko Z, Gallagher EJ. Diabetes and cancer. Endocrinol Metab Clin N Am. 2014;43:167-85. https://doi.org/10.1016/j.ecl.2013. 09.008

203. Zhu B, Wu X, Wu B, Pei D, Zhang L, Wei L. The relationship between diabetes and colorectal cancer prognosis: a meta-analysis based on the cohort studies. PLoS One. 2017;12:e176068. https://doi.org/10.1371/journal.pone.0176068.

204. Guraya SY. Association of type 2 diabetes mellitus and the risk of colorectal cancer: a meta-analysis and systematic review. World J Gastroenterol. 2015;21:6026-31. https://doi.org/10.3748/wjg. v21.i19.6026.

205. Hardefeldt PJ, Edirimanne S, Eslick GD. Diabetes increases the risk of breast cancer: a meta-analysis. Endocr Relat Cancer. 2012;19:793-803. https://doi.org/10.1530/ERC-12-0242.

206. Kaaks R, Rinaldi S, Key TJ, Berrino F, Peeters PHM, Biessy C, et al. Postmenopausal serum androgens, oestrogens and breast cancer risk: the European prospective investigation into cancer and nutrition. Endocr Relat Cancer. 2005;12:1071-82. https:// doi.org/10.1677/erc.1.01038.

207. Larsson SC, Mantzoros CS, Wolk A. Diabetes mellitus and risk of breast cancer: a meta-analysis. Int J Cancer. 2007;121:856-62. https://doi.org/10.1002/ijc.22717.

208. Karlin NJ, Amin SB, Buras MR, Kosiorek HE, Verona PM, Cook CB. Patient outcomes from lung cancer and diabetes mellitus: a matched case-control study. Future Sci OA. 2018;4:FSO248. https://doi.org/10.4155/fsoa-2017-0081.

209. Kasper JS, Giovannucci E. A meta-analysis of diabetes mellitus and the risk of prostate cancer. Cancer Epidemiol Biomark Prev Publ Am Assoc Cancer Res Cosponsored Am Soc Prev Oncol. 2006;15:2056 62. https://doi.org/10.1158/1055-9965.EPI-06-0410.

210. Lee J, Giovannucci E, Jeon JY. Diabetes and mortality in patients with prostate cancer: a meta-analysis. SpringerPlus. 2016;5. https://doi.org/10.1186/s40064-016-3233-y.

211. Yang X, So W-Y, Ma RCW, Kong APS, Xu G, Chan JCN. Diabetes and cancer: the mechanistic implications of epidemiological analyses 
from the Hong Kong Diabetes Registry. Diabetes Metab Res Rev. 2012;28:379-87. https://doi.org/10.1002/dmrr.2287.

212. Kong APS, Yang X, So W-Y, Luk A, Ma RCW, Ozaki R, et al. Additive effects of blood glucose lowering drugs, statins and renin-angiotensin system blockers on all-site cancer risk in patients with type 2 diabetes. BMC Med. 2014;12:76. https://doi. org/10.1186/1741-7015-12-76.

213. Guay C, Regazzi R. Circulating microRNAs as novel biomarkers for diabetes mellitus. Nat Rev Endocrinol. 2013;9:513-21. https:// doi.org/10.1038/nrendo.2013.86.

214. Tersey SA, Nishiki Y, Templin AT, Cabrera SM, Stull ND, Colvin $\mathrm{SC}$, et al. Islet $\beta$-cell endoplasmic reticulum stress precedes the onset of type 1 diabetes in the nonobese diabetic mouse model. Diabetes. 2012;61:818-27. https://doi.org/10.2337/db11-1293.

215. Poy MN, Hausser J, Trajkovski M, Braun M, Collins S, Rorsman $\mathrm{P}$, et al. miR-375 maintains normal pancreatic alpha- and beta-cell mass. Proc Natl Acad Sci U S A. 2009;106:5813-8. https://doi. org/10.1073/pnas.0810550106.

216. Poy MN, Eliasson L, Krutzfeldt J, Kuwajima S, Ma X, MacDonald PE, et al. A pancreatic islet-specific microRNA regulates insulin secretion. Nature. 2004;432:226-30. https://doi.org/ 10.1038/nature03076.

217. Erener S, Mojibian M, Fox JK, Denroche HC, Kieffer TJ. Circulating miR-375 as a biomarker of $\beta$-cell death and diabetes in mice. Endocrinology. 2013;154:603-8. https://doi.org/10. 1210/en.2012-1744.

218. Kanak MA, Takita M, Shahbazov R, Lawrence MC, Chung WY, Dennison AR, et al. Evaluation of microRNA375 as a novel biomarker for graft damage in clinical islet transplantation. Transplantation. 2015;99:1568-73. https://doi.org/10.1097/TP. 0000000000000625.

219. Nielsen LB, Wang C, Sørensen K, Bang-Berthelsen CH, Hansen L, Andersen M-LM, et al. Circulating levels of microRNA from children with newly diagnosed type 1 diabetes and healthy controls: evidence that miR-25 associates to residual beta-cell function and glycaemic control during disease progression. Exp Diabetes Res. 2012;2012: 896362. https://doi.org/10.1155/2012/896362.

220. Sebastiani G, Grieco FA, Spagnuolo I, Galleri L, Cataldo D, Dotta F. Increased expression of microRNA miR-326 in type 1 diabetic patients with ongoing islet autoimmunity. Diabetes Metab Res Rev. 2011;27:862-6. https://doi.org/10.1002/dmrr.1262.

221. Yang M, Ye L, Wang B, Gao J, Liu R, Hong J, et al. Decreased miR-146 expression in peripheral blood mononuclear cells is correlated with ongoing islet autoimmunity in type 1 diabetes patients 1miR-146. J Diabetes. 2015;7:158-65. https://doi.org/10.1111/ 1753-0407.12163.

222. Kuroda A, Rauch TA, Todorov I, Ku HT, Al-Abdullah IH, Kandeel $\mathrm{F}$, et al. Insulin gene expression is regulated by DNA methylation. PLoS One. 2009;4. https://doi.org/10.1371/journal.pone.0006953.

223. Herold KC, Usmani-Brown S, Ghazi T, Lebastchi J, Beam CA, Bellin MD, et al. $\beta$ cell death and dysfunction during type 1 diabetes development in at-risk individuals. J Clin Invest. 2015;125:1163-73. https://doi.org/10.1172/JCI78142.

224. Fisher MM, Watkins RA, Blum J, Evans-Molina C, Chalasani N, DiMeglio LA, et al. Elevations in circulating methylated and unmethylated preproinsulin DNA in new-onset type 1 diabetes. Diabetes. 2015;64:3867-72. https://doi.org/10.2337/db15-0430.

225. Akirav EM, Lebastchi J, Galvan EM, Henegariu O, Akirav M, Ablamunits V, et al. Detection of $\beta$ cell death in diabetes using differentially methylated circulating DNA. Proc Natl Acad Sci. 2011;108:19018-23. https://doi.org/10.1073/pnas.1111008108.

226. Lehmann-Werman R, Neiman D, Zemmour H, Moss J, Magenheim J, Vaknin-Dembinsky A, et al. Identification of tissue-specific cell death using methylation patterns of circulating DNA. Proc Natl Acad Sci. 2016;113:E1826-34. https://doi.org/ 10.1073/pnas.1519286113.

227. Pescador N, Pérez-Barba M, Ibarra JM, Corbatón A, MartínezLarrad MT, Serrano-Ríos M. Serum circulating microRNA profiling for identification of potential type 2 diabetes and obesity biomarkers. PLoS One. 2013;8:e77251. https://doi.org/10.1371/ journal.pone.0077251.

228. Zampetaki A, Kiechl S, Drozdov I, Willeit P, Mayr U, Prokopi M, et al. Plasma microRNA profiling reveals loss of endothelial miR126 and other microRNAs in type 2 diabetes. Circ Res. 2010;107: 810-7. https://doi.org/10.1161/CIRCRESAHA.110.226357.

229. Polivka J Jr, Altun I, Golubnitschaja O. Pregnancy-associated breast cancer: the risky status quo and new concepts of predictive medicine. EPMA J. 2018;9:1-13. https://doi.org/10.1007/s13167-018-0129-7.

230. Duarte AA, Mohsin S, Golubnitschaja O. Diabetes care in figures: current pitfalls and future scenario. EPMA J. 2018;9:125-31. https://doi.org/10.1007/s13167-018-0133-y.

231. Goncharenko V, Bubnov R, Polivka J Jr, Zubor P, Biringer K, Bielik T, et al. Vaginal dryness: individualised patient profiles, risks and mitigating measures. EPMA J. 2019;10:73-9. https:// doi.org/10.1007/s13167-019-00164-3.

232. Samec M, Liskova A, Koklesova L, Samuel SM, Zhai K, Buhrmann $\mathrm{C}$, et al. Flavonoids against the Warburg phenotype - concepts of predictive, preventive and personalised medicine to cut the Gordian knot of cancer cell metabolism. EPMA J. 2020;11:377-98. https://doi. org/10.1007/s13167-020-00217-y.

233. Seifirad S, Haghpanah V. Inappropriate modeling of chronic and complex disorders: how to reconsider the approach in the context of predictive, preventive and personalized medicine, and translational medicine. EPMA J. 2019;10:195-209. https://doi.org/10. 1007/s13167-019-00176-z.

234. Golubnitschaja O, Costigliola V. Common origin but individual outcomes: time for new guidelines in personalized healthcare. Pers Med. 2010;7:561-8. https://doi.org/10.2217/pme.10.42.

235. Janssens JP, Schuster K, Voss A. Preventive, predictive, and personalized medicine for effective and affordable cancer care. EPMA J. 2018:9:113-23. https://doi.org/10.1007/s13167-018-0130-1.

236. Xu B, Tao T, Wang Y, Fang F, Huang Y, Chen S, et al. hsa-miR135a-1 inhibits prostate cancer cell growth and migration by targeting EGFR. Tumour Biol J Int Soc Oncodev Biol Med. 2016;37:14141-51. https://doi.org/10.1007/s13277-016-5196-6.

237. Chaari L, Golubnitschaja O. Covid-19 pandemic by the "realtime" monitoring: the Tunisian case and lessons for global epidemics in the context of 3PM strategies. EPMA J. 2020;11:133-8. https://doi.org/10.1007/s13167-020-00207-0.

238. Radanliev P, De Roure D, Walton R, Van Kleek M, Montalvo RM, Santos O, et al. COVID-19 what have we learned? The rise of social machines and connected devices in pandemic management following the concepts of predictive, preventive and personalized medicine. EPMA J. 2020;11:311-32. https://doi.org/10.1007/ s13167-020-00218-X.

239. Zhao X, Wang K, Zuo P, Liu Y, Zhang M, Xie S, et al. Early decrease in blood platelet count is associated with poor prognosis in COVID-19 patients - indications for predictive, preventive, and personalized medical approach. EPMA J. 2020;11:139-45. https://doi.org/10.1007/s13167-020-00208-z.

240. Lipman M, Chambers RC, Singer M, Brown JS. SARS-CoV-2 pandemic: clinical picture of COVID-19 and implications for research. Thorax. 2020;75:614-6. https://doi.org/10.1136/thoraxjnl2020-215024.

241. Vabret N, Britton GJ, Gruber C, Hegde S, Kim J, Kuksin M, et al. Immunology of COVID-19: current state of the science. 
Immunity. 2020;52:910-41. https://doi.org/10.1016/j.immuni. 2020.05.002.

242. Nailwal H, Chan FK-M. Necroptosis in anti-viral inflammation. Cell Death Differ. 2019;26:4-13. https://doi.org/10.1038/s41418018-0172-x.

243. Scozzi D, Cano M, Ma L, Zhou D, Zhu JH, O’Halloran JA, Goss C, Rauseo AM, Liu Z, Peritore V, et al. Circulating mitochondrial DNA is an early indicator of severe illness and mortality from COVID-19. bioRxiv 2020, doi:https://doi.org/10.1101/2020.07.30.227553.
244. Golubnitschaja O, Baban B, Boniolo G, Wang W, Bubnov R, Kapalla M, et al. Medicine in the early twenty-first century: paradigm and anticipation - EPMA position paper 2016. EPMA J. 2016;7:23. https://doi.org/10.1186/s13167-016-0072-4.

Publisher's note Springer Nature remains neutral with regard to jurisdictional claims in published maps and institutional affiliations. 